Article

\title{
Energy Consumption and Economic Analyses of a Supercritical Water Oxidation System with Oxygen Recovery
}

\author{
Fengming Zhang ${ }^{1,2, *}$, Jiulin Chen ${ }^{1}$, Chuangjian $\mathrm{Su}^{1}$ and Chunyuan $\mathrm{Ma}^{3}$ \\ 1 Guangzhou Institutes of Advanced Technology, Chinese Academy of Sciences, Guangzhou 511458, China; \\ jlchen_sust@163.com (J.C.); suchuangiian501@126.com (C.S.) \\ 2 Shenzhen Institutes of Advanced Technology, Chinese Academy of Sciences, Shenzhen 518055, China \\ 3 National Engineering Laboratory for Coal-fired Pollutants Emission Reduction, Shandong University, \\ Jinan 250061, China; pheres8@mail.sdu.edu.cn \\ * Correspondence: fm.zhang@giat.ac.cn; Tel.: +86-020-2291-2754
}

Received: 15 October 2018; Accepted: 14 November 2018; Published: 16 November 2018

check for updates

\begin{abstract}
Oxygen consumption is one of the factors that contributes to the high treatment cost of a supercritical water oxidation (SCWO) system. In this work, we proposed an oxygen recovery (OR) process for an SCWO system based on the solubility difference between oxygen and $\mathrm{CO}_{2}$ in high-pressure water. A two-stage gas-liquid separation process was established using Aspen Plus software to obtain the optimized separation parameters. Accordingly, energy consumption and economic analyses were conducted for the SCWO process with and without OR. Electricity, depreciation, and oxygen costs contribute to the major cost of the SCWO system without OR, accounting for $46.18,30.24$, and $18.01 \$ \cdot \mathrm{t}^{-1}$, respectively. When OR was introduced, the total treatment cost decreased from $56.80 \$ \cdot \mathrm{t}^{-1}$ to $46.17 \$ \cdot \mathrm{t}^{-1}$, with a reduction of $18.82 \%$. Operating cost can be significantly reduced at higher values of the stoichiometric oxygen excess for the SCWO system with OR. Moreover, the treatment cost for the SCWO system with OR decreases with increasing feed concentration for more reaction heat and oxygen recovery.
\end{abstract}

Keywords: supercritical water oxidation; high-pressure separation; oxygen recovery; energy recovery; economic analysis

\section{Introduction}

Supercritical water $(\mathrm{SCW})\left(P>22.1 \mathrm{MPa}, \mathrm{T}>374{ }^{\circ} \mathrm{C}\right)$ has unique thermo-physical characteristics [1], which can dissolve organic compounds and gases to form a homogeneous mixture without mass transfer resistance [2,3]. SCW has been widely used to treat organic waste by supercritical water oxidation (SCWO) or supercritical water gasification (SCWG) for high efficiency and low residence time [3-5]. In the $\mathrm{SCWO}$ process, no $\mathrm{SO}_{2}$ or $\mathrm{NO}_{X}$ by-products during organic waste degradation emit [6-8]. Although SCWO has many unique advantages in treating wastewater, some technical problems, such as corrosion and salt plugging, have hindered its development for years $[9,10]$. Inorganic acids (e.g., $\mathrm{HCl}$ and $\mathrm{H}_{2} \mathrm{SO}_{4}$ ), combined with high temperature and high oxygen concentration, can cause severe corrosion of the reactor and other devices [11]. Inorganic salt is hardly soluble in SCW, which leads to the plugging of the reactor, as well as the preheating and cooling sections [12]. At present, an effective solution for corrosion and salt plugging is the use of a transpiring wall reactor (TWR). A TWR typically consists of a dual shell with an outer pressure-resistant vessel and an inner porous tube. Transpiring water at subcritical temperatures passes through the porous pipe to form a protective film on its inner surface. This water film can prevent reactants from spreading to the porous 
wall and dissolve inorganic salt. Numerous studies have proven that TWR plays an effective role in preventing corrosion and salt plugging [13-15].

A high treatment cost, which is due to material input (such as oxidants and additives) and energy consumption during the pressurization and heating steps, is another obstacle that hinders the SCWO application. Treatment cost is determined according to the adopted equipment, treatment capacity, concentrations, and types of organic matter, operating conditions, and staff costs. At present, the treatment cost for an SCWO system with $1000 \mathrm{~kg} / \mathrm{h}$ wet organic waste and an organic matter content of $10 \mathrm{wt} \%$ typically ranges from tens to hundreds of dollars [16]. Energy recovery is the leading method for reducing energy consumption and operating cost. An autothermal operation with a certain feed concentration $(>2 \mathrm{wt} \%)$ can be achieved under ideal conditions [17-19]. Power generation is another potential application that uses high-pressure and high-temperature reactor effluent [20-22]. However, the reactor effluent in an SCWO system with TWR is cooled to subcritical temperature $\left(<360^{\circ} \mathrm{C}\right)$ for transpiring water injection at a low temperature to avoid salt plugging [13]. Accordingly, feedstock preheating and hot water/steam production may be more realistic and effective choices $[23,24]$.

Oxygen, the most popular oxidant in SCWO systems, is another major source of cost. Results have indicated that a stoichiometric oxygen excess $(R)$ of 1.05 may be sufficient for complete oxidation of organic wastewater [16]. However, a higher amount of oxygen is required in the pilot or industrial plant, which is mainly due to the local heterogeneous state in the reactor. Thus, twice the value of $R$ (or even higher) is obtained, which leads to oxygen loss. Xu et al. [25] conducted an economic analysis of urban sludge via SCWO using a $2.5 \mathrm{t} /$ day demonstration device. The operating cost was approximately $83.1 \$ \cdot \mathrm{t}^{-1}$, with oxygen cost accounting for $25 \%$ of the total amount. Zhang et al. [26] analyzed a $100 \mathrm{t} /$ day SCWO system for high-concentration printing and dyeing wastewater; the operating cost of the system was $10.3 \$ \cdot t^{-1}$, with oxygen cost accounting for $37 \%$ of the total amount. Shen et al. [27] conducted an economic analysis of an SCWO system with TWR. The feed was $300 \mathrm{~m}^{3} /$ day, with an initial concentration of $40,000 \mathrm{mg} / \mathrm{L}$ chemical oxygen demand; the cost was $4.99 \mathrm{\$} \cdot \mathrm{t}^{-1}$, with oxygen cost accounting for $71.8 \%$ of the total amount. Thus, oxygen consumption control will be an important solution for reducing operating cost.

In addition, $\mathrm{CO}_{2}$ is another primary gas in reactor effluent. However, it is low in purity due to excess oxygen consumption, which is the main obstacle that inhibits $\mathrm{CO}_{2}$ recovery and utilization. Thus, recovering $\mathrm{CO}_{2}$ with high purity may be another solution for reducing the operating cost of SCWO systems. The low operating cost calculated by Shen [27] is mainly attributed to the benefit of $\mathrm{CO}_{2}$ recovery. Abeln [28] reported that the operating cost of a $100 \mathrm{~kg} / \mathrm{h} \mathrm{SCWO-TWR} \mathrm{plant} \mathrm{is}$ approximately $659 € / \mathrm{t}$, and by-product income, such as surplus heat energy and $\mathrm{CO}_{2}$, must be ensured to obtain a comparably low operating cost.

Species recovery can considerably reduce operating cost for less input and additional income. However, only a few studies have focused on this issue, and a simple operation process with low energy consumption is urgently required for species recovery. In the current work, a species recovery process based on high-pressure water absorption was proposed to separate and recover oxygen and $\mathrm{CO}_{2}$. A two-stage gas-liquid separation process was established using Aspen Plus V8.0. Reasonable thermodynamic models for high-pressure separation were evaluated to identify the optimized separation parameters. Accordingly, SCWO processes with and without oxygen recovery (OR) were simulated, and energy consumption and economic analyses were conducted.

\section{Proposal of OR for SCWO Systems}

Baranenko et al. [29] tested the solubility of oxygen and $\mathrm{CO}_{2}$ in high-pressure water at temperatures ranging from $0{ }^{\circ} \mathrm{C}$ to $360{ }^{\circ} \mathrm{C}$ and pressures from $1 \mathrm{MPa}$ to $20 \mathrm{MPa}$. The solubility of oxygen (Figure 1a) and $\mathrm{CO}_{2}$ (Figure $1 \mathrm{~b}$ ) increases with increasing pressure, but the effect of temperature on solubility does not exhibit a distinct trend. At low pressures, an evident reduction in solubility is observed as temperature increases. At high pressures, solubility initially decreases, then increases, and finally decreases with increasing temperature. Thus, two solubility extremes occur in the wave 
curve of the high-pressure zone. Moreover, the solubility of $\mathrm{CO}_{2}$ is nearly one order of magnitude higher than that of oxygen under the same conditions. Given that reactor effluent is mostly composed of oxygen, $\mathrm{CO}_{2}$, and water, the ratio of oxygen to $\mathrm{CO}_{2}$ in the gaseous phase under different conditions is calculated using the typical effluent composition in our previous pilot plant.
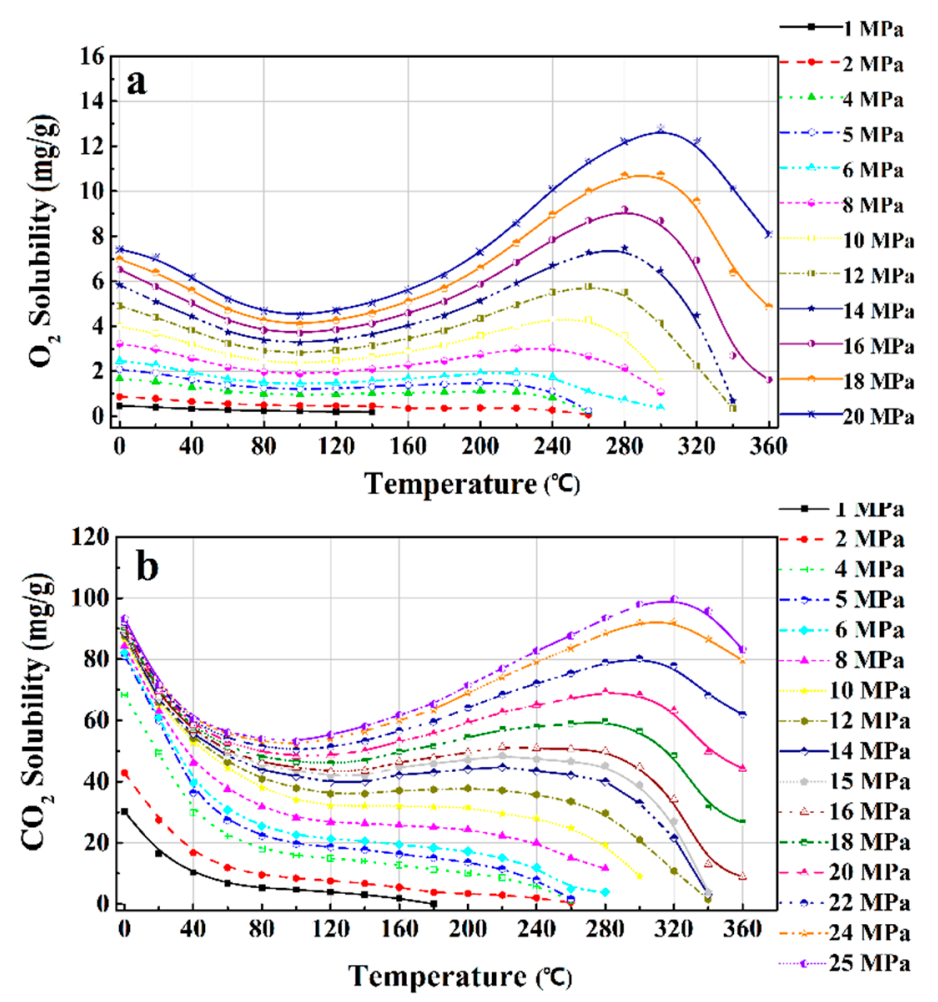

Figure 1. The solubility of oxygen (a) and carbon dioxide (b) in the high-pressure water.

Over $80 \%$ of oxygen cannot be dissolved in high-pressure water and occurs in gaseous phase at $P<9 \mathrm{MPa}$ and $20{ }^{\circ} \mathrm{C}<\mathrm{T}<360^{\circ} \mathrm{C}$, as shown in Figure 2a. In addition, Figure $2 \mathrm{~b}$ shows that $\mathrm{CO}_{2}$ can be dissolved completely in water under certain conditions. Moreover, low temperatures are conducive to dissolving $\mathrm{CO}_{2}$ in water. $\mathrm{CO}_{2}$ can dissolve completely in water at temperatures below $20{ }^{\circ} \mathrm{C}$ when $P=2 \mathrm{MPa}$; however, temperature can be increased to $280^{\circ} \mathrm{C}$ when $P=10 \mathrm{MPa}$. Thus, the temperatures for completely dissolving $\mathrm{CO}_{2}$ in water can be increased at high pressures. Figure $2 \mathrm{c}$ shows the releasing ratio difference in gaseous phase between oxygen and $\mathrm{CO}_{2}$. The temperature zone gradually widens with increasing pressure to obtain a high releasing ratio, but the releasing ratio difference slowly decreases. The temperature zone between $20^{\circ} \mathrm{C}$ and $60^{\circ} \mathrm{C}$ can reach a releasing ratio difference of $80 \%$ at $2 \mathrm{MPa}$. However, when pressure is increased to $8 \mathrm{MPa}$, the temperature zone can be widened to a range of $20^{\circ} \mathrm{C}$ to $240{ }^{\circ} \mathrm{C}$. These results have motivated us to develop a solution for separating oxygen and $\mathrm{CO}_{2}$ by adjusting reactor effluent parameters. Thus, a new process for improving oxygen utilization rate in SCWO systems [30] is proposed, as shown in Figure 3.

In the proposed SCWO process, excess oxygen and preheated organic waste are injected from the top of the TWR, which initiates the oxidation reaction. Simultaneously, two branches of transpiring water with different temperatures are injected from the side of the TWR to protect the reactor. The reactor effluent first enters a high-pressure gas-liquid separator after heat exchange and depressurization. Most of the oxygen is released in gaseous phase, whereas most of the $\mathrm{CO}_{2}$ is dissolved in aqueous phase for the solubility difference between oxygen and $\mathrm{CO}_{2}$ in water, thereby achieving the separation of oxygen and $\mathrm{CO}_{2}$. Subsequently, oxygen is reused through the oxygen circulation pump. The aqueous fluid from the high-pressure gas-liquid separator is adjusted further 
and injected into a low-pressure separator, whereas $\mathrm{CO}_{2}$ is released and collected. Therefore, oxygen and $\mathrm{CO}_{2}$ are separated and recovered.

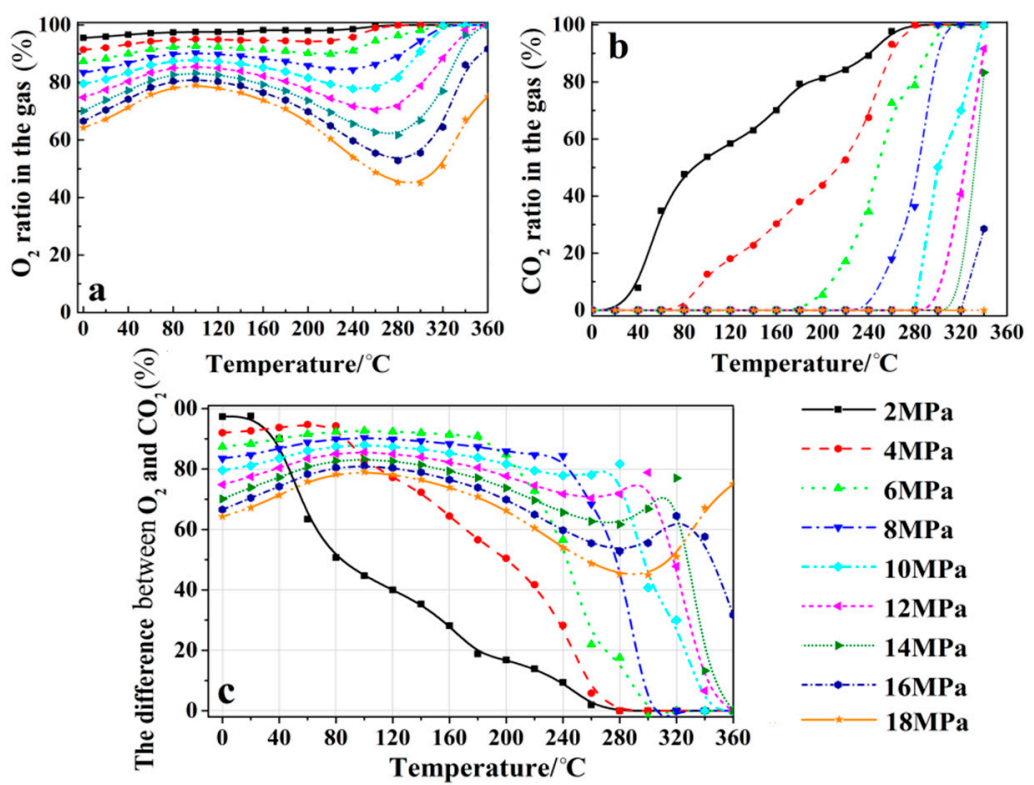

Figure 2. The releasing ratio difference between oxygen and carbon dioxide at different pressures and temperatures based on our previous experimental results, in the reactor effluent, water flow: 46.044 $\mathrm{kg} / \mathrm{h}$, oxygen flow: $0.448 \mathrm{~kg} / \mathrm{h}$, carbon dioxide flow: $0.836 \mathrm{~kg} / \mathrm{h},(\mathbf{a}) \mathrm{O}_{2}$ ratio in the gas, $(\mathbf{b}) \mathrm{CO}_{2}$ ratio in the gas, (c) the ratio difference between $\mathrm{O}_{2}$ and $\mathrm{CO}_{2}$.

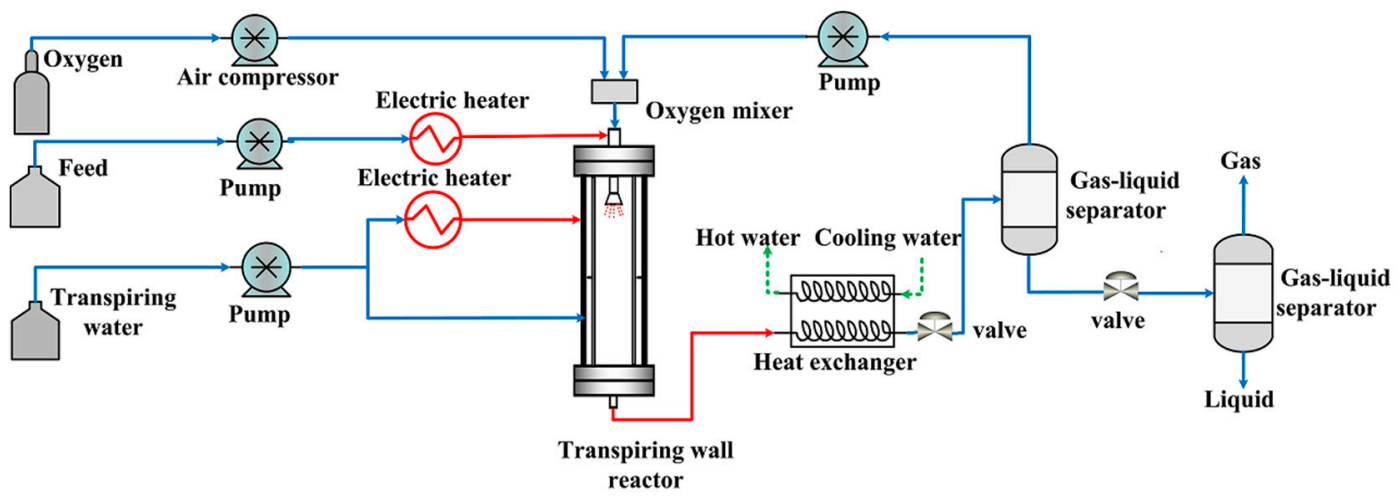

Figure 3. The simplified diagram of a SCWO system to increase the oxygen utilization rate.

\section{High-Pressure Separation for Reactor Effluent}

\subsection{High-Pressure Separation Process}

To identify optimized parameters for OR, a simulation flow of a two-step separation process for reactor effluent based on high-pressure water absorption was first established using Aspen Plus V8.0 (Figure 4). High- and low-pressure gas-liquid separators were introduced to separate and recover oxygen and $\mathrm{CO}_{2}$. 


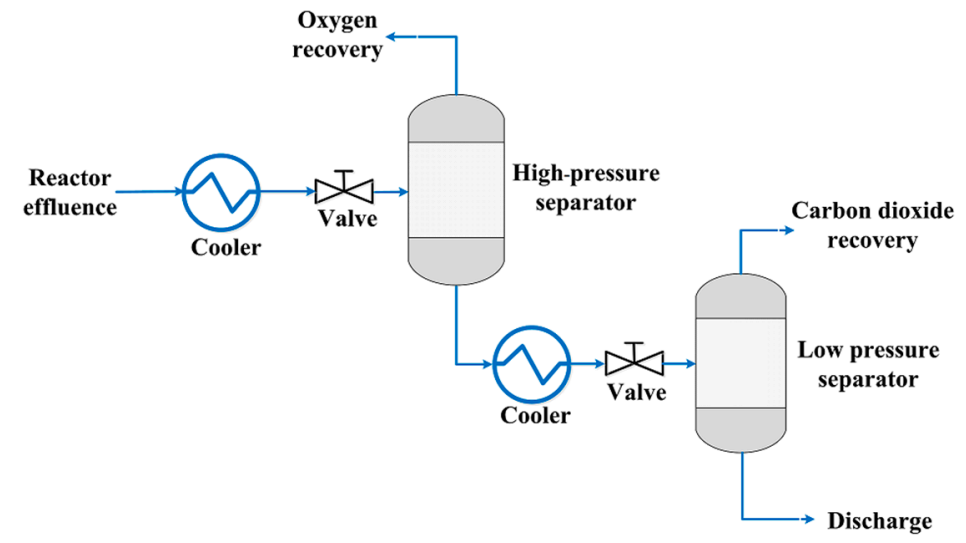

Figure 4. The simulation flow of the high-pressure water absorption for oxygen recovery.

\subsection{Definition of Process Parameters}

The OR ratio $\left(\gamma_{\mathrm{O} 2}\right)$ is defined as the oxygen in the gaseous phase of the high-pressure separator divided by the oxygen in the reactor effluent:

$$
\gamma_{\mathrm{O}_{2}}=\frac{F_{\mathrm{O}_{2, g}}^{\prime}}{F_{\mathrm{O}_{2}, g}^{\prime}+F_{\mathrm{O}_{2}, l}^{\prime}}
$$

where $F^{\prime}{ }_{2, g}$ and $F^{\prime}{ }_{\mathrm{O}_{2}, l}$ are the oxygen mass flows in the gaseous and aqueous phases, respectively, of the high-pressure separator.

Oxygen purity $\left(\beta_{\mathrm{O} 2}\right)$ is defined as the oxygen ratio in the gaseous phase of the high-pressure separator, which can be calculated as follows:

$$
\beta_{\mathrm{O}_{2}}=\frac{F_{\mathrm{O}_{2, g}}^{\prime}}{F^{\prime} \mathrm{O}_{2, g}+F^{\prime} \mathrm{CO}_{2, g}+F^{\prime} \mathrm{H}_{2} \mathrm{O}, g}
$$

where $F^{\prime} \mathrm{CO}_{2, g}$ and $F^{\prime} \mathrm{H}_{2} \mathrm{O}, g$ are the mass flows of $\mathrm{CO}_{2}$ and water in the gaseous phase, respectively. Water can be typically disregarded when its content is small.

Similarly, the $\mathrm{CO}_{2}$ recovery ratio $\left(\gamma_{\mathrm{CO} 2}\right)$ is defined as the $\mathrm{CO}_{2}$ in the gaseous phase of the low-pressure separator divided by the $\mathrm{CO}_{2}$ in the reactor effluent:

$$
\gamma_{\mathrm{CO}_{2}}=\frac{F^{\prime \prime} \mathrm{CO}_{2, g}}{F_{\mathrm{CO}_{2, g}}^{\prime}+F_{\mathrm{CO}_{2}, l}^{\prime}}
$$

where $F^{\prime \prime} \mathrm{CO}_{2, g}$ is the $\mathrm{CO}_{2}$ mass flow in the gaseous phase of the low-pressure separator, and $F_{\mathrm{CO}_{2}, l}^{\prime}$ is the $\mathrm{CO}_{2}$ mass flow in the aqueous phase of the high-pressure separator.

$\mathrm{CO}_{2}$ purity $\left(\beta_{\mathrm{CO} 2}\right)$ is defined as the $\mathrm{CO}_{2}$ ratio in the gaseous phase of the low-pressure separator, which can be calculated as follows:

$$
\beta_{\mathrm{CO}_{2}}=\frac{F^{\prime \prime} \mathrm{CO}_{2, g}}{F^{\prime \prime} \mathrm{O}_{2, g}+F^{\prime \prime} \mathrm{CO}_{2, g}+F^{\prime \prime} \mathrm{H}_{2} \mathrm{O}, g}
$$

where $F^{\prime \prime} \mathrm{O}_{2, g}$ and $F^{\prime \prime} \mathrm{H}_{2} \mathrm{O}, g$ are the mass flows of oxygen and water, respectively, in the gaseous phase of the low-pressure separator, and water can be typically disregarded when its content is small.

The mass flow rate of oxygen is calculated using a constant $R$ [18], which is defined as follows:

$$
R=\frac{F_{\mathrm{O}_{2}}}{1.5 F_{f} \omega}
$$


where $F_{\mathrm{O}_{2}}(\mathrm{~kg} / \mathrm{h})$ and $F_{\mathrm{f}}(\mathrm{kg} / \mathrm{h})$ are the mass flow rates of oxygen and the feed, respectively; and $\omega$ $(\mathrm{wt} \%)$ is the methanol concentration in the feed.

\subsection{Thermodynamic Property Models}

The selection of an appropriate model for estimating the thermodynamic properties of reactor effluent is one of the most important steps that can affect the simulation results. To date, no model has been adopted for all the components and processes. Moreover, the same model cannot be used under all operating conditions, especially at wide ranges of pressure $(0.1-23 \mathrm{MPa})$ and temperature $\left(20-360^{\circ} \mathrm{C}\right)$. Therefore, an appropriate method for estimating the separation process should be carefully selected. Aspen Plus includes a large databank of thermodynamic properties and transport models with the corresponding mixing rules for estimating mixture properties. Several potential thermodynamic models recommended by Aspen Plus were selected and tested (as listed in Table 1) based on the composition of our reactor effluent (i.e., water, $\mathrm{CO}_{2}$, and oxygen) and the range of the operating conditions. The selected models were simulated with default interaction parameters for the preliminary assessment due to the lack of component interaction coefficients within a large range. The $\gamma_{\mathrm{O} 2}$ and $\gamma_{\mathrm{CO} 2}$ values at different pressure and temperature values with 10 recommended thermodynamic models were plotted in Figure 5. Additionally, the ideal results calculated from the experimental solubility data of Baranenko et al. [29] were also plotted for the comparison and verification of the thermodynamic models. In the ideal results calculation, the reactor effluent was assumed to conduct an ideal separation in the high-pressure and low-pressure separators, and the interaction between $\mathrm{O}_{2}$ and $\mathrm{CO}_{2}$ has been ignored.

Identifying an accurate thermodynamic model that can fulfill the standard for $\mathrm{CO}_{2}$ and oxygen within a wide range of temperature and pressure values is difficult, as shown in Figure 5. The $\gamma_{\mathrm{O} 2}$ (Figure 5a,c,e,g,i,k) calculated using the BWR-LS, PR-BM, SR-POLAR, SRK, PSRK, RKS-BM, and LK-Plock models agree well with the ideal results calculated from the experimental solubility data (red curves) of Baranenko et al. [29]. By contrast, the comparison of $\gamma_{\mathrm{CO} 2}$ between the thermodynamic models and the ideal results present more complex information. At $0.1 \mathrm{MPa}$ (Figure $5 \mathrm{~b}$ ), all the models can accurately predict $\gamma_{\mathrm{CO} 2}$. At $2 \mathrm{MPa}$ (Figure $5 \mathrm{~d}$ ) and $4 \mathrm{MPa}$ (Figure $5 \mathrm{f}$ ), only the PSRK, RKS-BM, and RKS-MHV2 models exhibit accurate prediction performance in terms of trend and value. At higher pressures (i.e., 6, 8, and $10 \mathrm{MPa}$ ), only the PSRK model (magenta curves) can achieve good prediction performance, with a maximal deviation of less than $20 \%$ (Figure $5 \mathrm{~h}, \mathrm{j}, \mathrm{l}$ ). Thus, PSRK is selected as the thermodynamic model for the high-pressure separation process in this study under the comprehensive consideration of $\gamma_{\mathrm{O} 2}$ and $\gamma_{\mathrm{CO} 2}$. A detailed model expression for PSRK is available in the literature [31].

Table 1. Potential thermodynamic property models in Aspen Plus for the process.

\begin{tabular}{cc}
\hline Aspen Plus Property Model & Model Name \\
\hline BWR-LS & Benedict-Webb-Rubin-Lee-Starling \\
PR-BM & Peng-Robinson-Boston-Mathias \\
SR-POLAR & Schwarzentruber-Renon-POLAR \\
SRK & Soave-Redlich-Kwong \\
PSRK & Predictive Redlich-Kwong-Soave \\
RKS-BM & Redlich-Kwong-Soave-Boston-Mathias \\
LK-Plock & Lee-Kesler-Plock \\
RK-SWS & Redlich-Kwong-Soave-Wong-Sandler \\
PR-MHV2 & Peng-Robinson-MHV2 \\
PR-WS & Peng-Robinson-Wong-Sandler \\
RKS-MHV2 & Redlich-Kwong-Soave-MHV2 \\
\hline
\end{tabular}




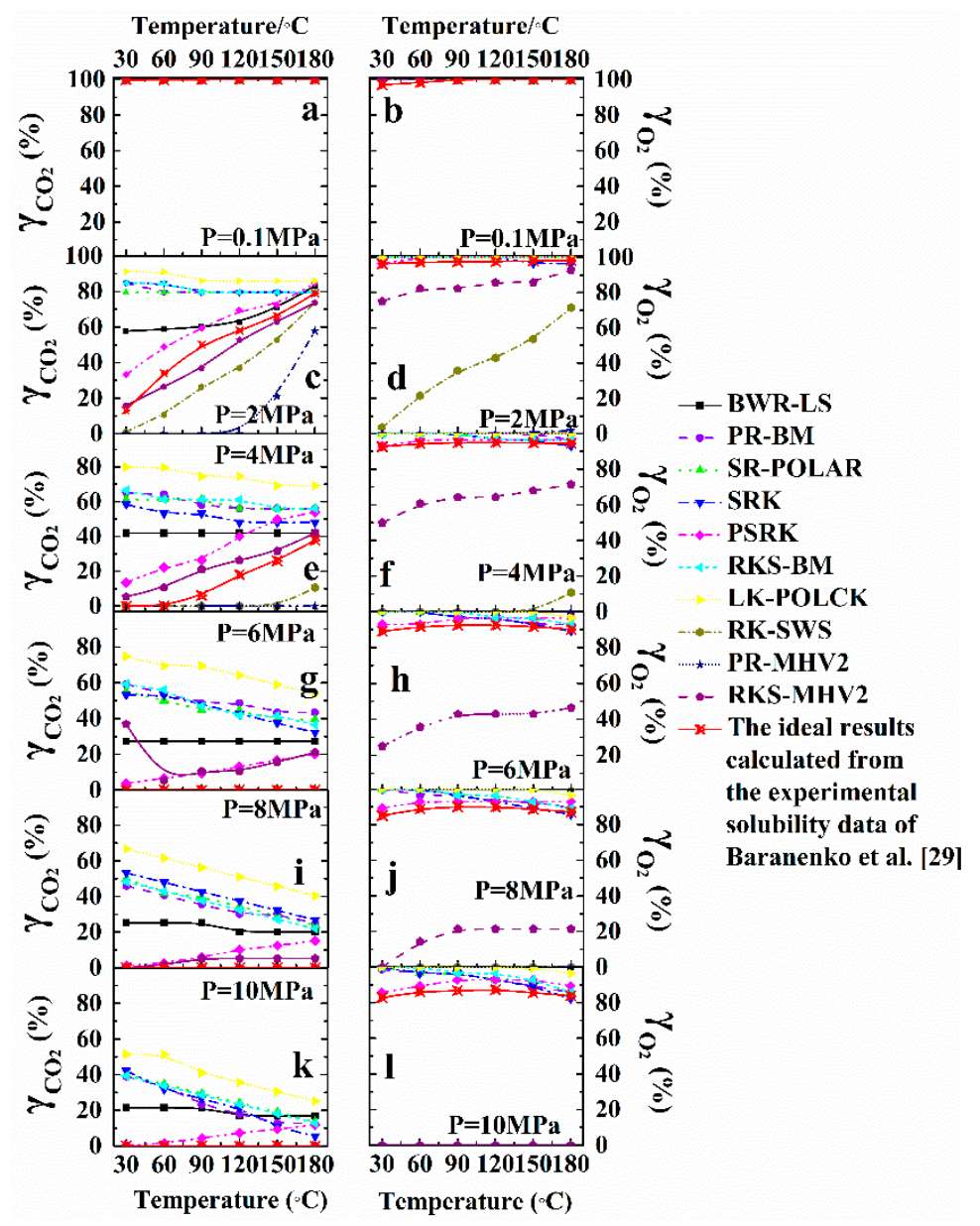

Figure 5. Comparisons of the ideal results calculated from the experimental solubility data and simulation results at different pressures and temperatures, (a) $\gamma_{\mathrm{O} 2}$ at $P=0.1 \mathrm{MPa},(\mathbf{b}) \gamma_{\mathrm{CO} 2}$ at $P=0.1 \mathrm{MPa}$, (c) $\gamma_{\mathrm{O} 2}$ at $P=2 \mathrm{MPa}$, (d) $\gamma_{\mathrm{CO} 2}$ at $P=2 \mathrm{MPa}$, (e) $\gamma_{\mathrm{O} 2}$ at $P=4 \mathrm{MPa}$, (f) $\gamma_{\mathrm{CO} 2}$ at $P=4 \mathrm{MPa}$, (g) $\gamma_{\mathrm{O} 2}$ at $P=6 \mathrm{MPa},\left(\right.$ h) $\gamma_{\mathrm{CO} 2}$ at $P=6 \mathrm{MPa}$, (i) $\gamma_{\mathrm{O} 2}$ at $P=8 \mathrm{MPa},(\mathbf{j}) \gamma_{\mathrm{CO} 2}$ at $P=8 \mathrm{MPa},(\mathbf{k}) \gamma_{\mathrm{O} 2}$ at $P=10 \mathrm{MPa},(\mathbf{l}) \gamma_{\mathrm{CO} 2}$ at $P=10 \mathrm{MPa}$.

\subsection{Effects of Operating Parameters}

\subsubsection{Stoichiometric Oxygen Excess}

The interaction between the high- and low-pressure separators typically results in different recovery ratio and purity values for oxygen and $\mathrm{CO}_{2}$. For convenience, the separation parameters of the low-pressure separator are set under ambient conditions $\left(P=0.1 \mathrm{MPa}, T=20^{\circ} \mathrm{C}\right)$ and, thus, we focus only on the separation parameters of the high-pressure separator.

Figure 6(a1-a4,b1-b4) show that a temperature increase or a pressure decrease is favorable for increasing $\gamma_{\mathrm{O} 2}$ but unfavorable for increasing $\beta_{\mathrm{O} 2} . R=1.5$ is used as an example. $\gamma_{\mathrm{O} 2}$ is $89.3 \%$ at $P=8 \mathrm{MPa}$ and $T=20^{\circ} \mathrm{C}$, and it increased to $92.8 \%$ when pressure decreased to $5 \mathrm{MPa}$. $\gamma_{\mathrm{O} 2}$ increased further to $96.4 \%$ when pressure and temperature were modified to $5 \mathrm{MPa}$ and $90{ }^{\circ} \mathrm{C}$, respectively (Figure 6(a1)). Similarly, $\beta_{\mathrm{O} 2}$ is $78.5 \%$ at $P=8 \mathrm{MPa}$ and $T=20^{\circ} \mathrm{C}$. It decreased to $70.1 \%$ when pressure was reduced to $5 \mathrm{MPa}$ and to $56.5 \%$ when pressure and temperature were adjusted to $5 \mathrm{MPa}$ and $90{ }^{\circ} \mathrm{C}$, respectively (Figure 6(b1)). 


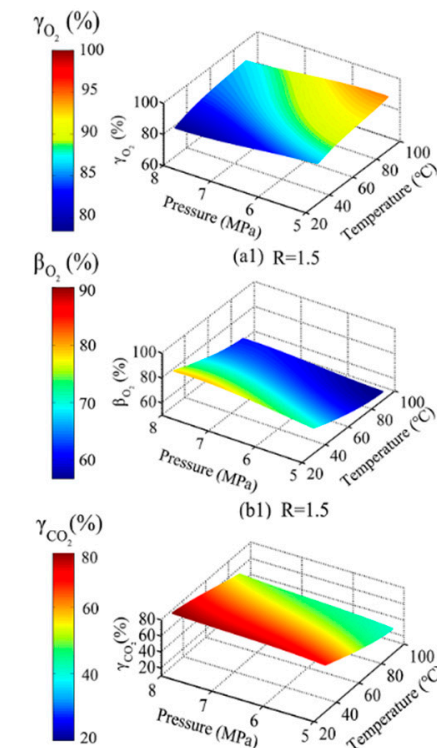

(cl) $\mathrm{R}=1.5$

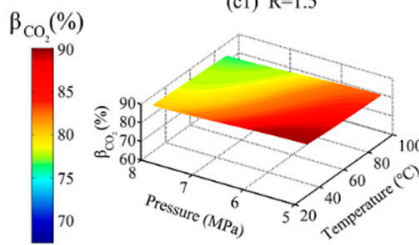

(d1) $\mathrm{R}=1.5$

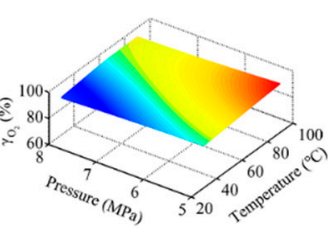

(a2) $\mathrm{R}=2$

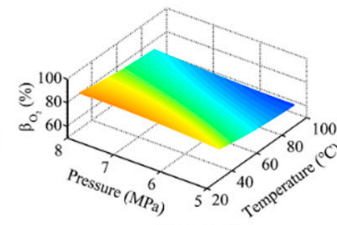

(b2) $\mathrm{R}=2$

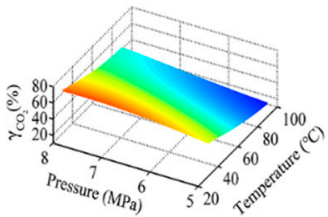

(c2) $\mathrm{R}=2$

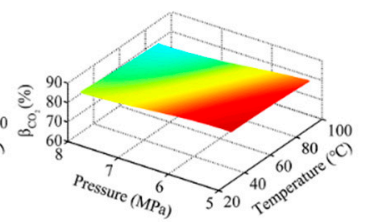

(d2) $\mathrm{R}=2$

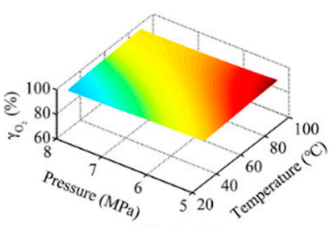

(a3) $\mathrm{R}=2.5$

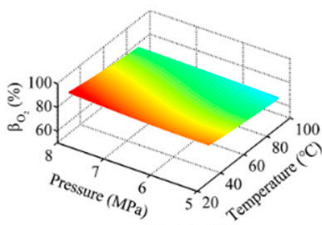

(b3) $\mathrm{R}=2.5$

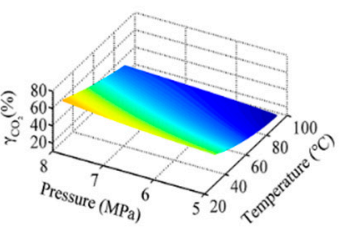

(c3) $\mathrm{R}=2.5$

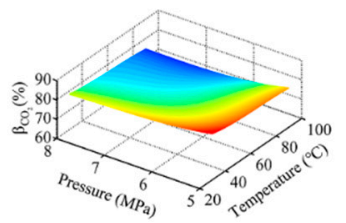

(d3) $\mathrm{R}=2.5$

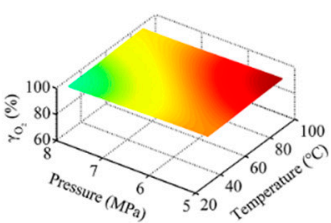

(a4) $\mathrm{R}=3$

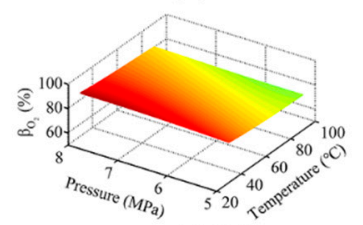

(b4) $\mathrm{R}=3$

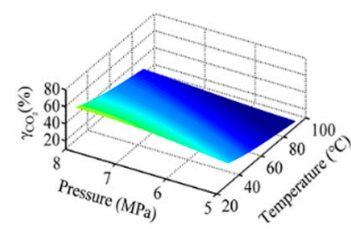

(c4) $\mathrm{R}=3$

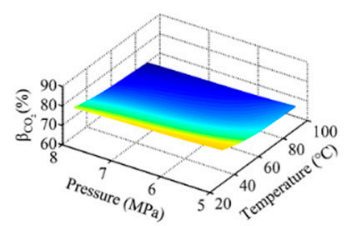

(d4) $\mathrm{R}=3$

Figure 6. The effect of $R$ on the performance of the high-pressure and low-pressure separators, (a1) $\gamma_{\mathrm{O} 2}$ at $R=1.5$, (a2) $\gamma_{\mathrm{O} 2}$ at $R=2,(\mathbf{a} 3) \gamma_{\mathrm{O} 2}$ at $R=2.5$, (a4) $\gamma_{\mathrm{O} 2}$ at $R=3,(\mathbf{b} 1) \beta_{\mathrm{O} 2}$ at $R=1.5,(\mathbf{b} 2) \beta_{\mathrm{O} 2}$ at $R=2$, (b3) $\beta_{\mathrm{O} 2}$ at $R=2.5$, (b4) $\beta_{\mathrm{O} 2}$ at $R=3$, (c1) $\gamma_{\mathrm{CO} 2}$ at $R=1.5$, (c2) $\gamma_{\mathrm{CO} 2}$ at $R=2$, (c3) $\gamma_{\mathrm{CO} 2}$ at $R=2.5$, (c4) $\gamma_{\mathrm{CO} 2}$ at $R=3,(\mathbf{d} 1) \beta_{\mathrm{CO} 2}$ at $R=1.5,(\mathbf{d} 2) \beta_{\mathrm{CO} 2}$ at $R=2,(\mathbf{d} 3) \beta_{\mathrm{CO} 2}$ at $R=2.5$, and $(\mathbf{d} 4) \beta_{\mathrm{CO} 2}$ at $R=3$.

The input of the low-pressure separator came from the aqueous mixture of the high-pressure separator. Thus, $\gamma_{\mathrm{CO} 2}$ and $\beta_{\mathrm{CO} 2}$ in the low-pressure separator are dependent on the separation parameters of the high-pressure separator. A standard for the high-pressure separator is first defined with high values of $\gamma_{\mathrm{O} 2}(>80 \%)$ and $\beta_{\mathrm{O} 2}(>70 \%)$ to narrow down the parameter range. The separating pressure and temperature values that can fulfill the standard can then be obtained. Subsequently, $\gamma_{\mathrm{CO} 2}$ and $\beta_{\mathrm{CO} 2}$ are analyzed based on the high-pressure separation results. Figure 6(c1-c4) show that a temperature increase or a pressure decrease in the high-pressure separator decreases $\gamma_{\mathrm{CO} 2}$, which is contrary to the effects of pressure and temperature on $\gamma_{\mathrm{O} 2} . R=1.5$ is used as an example. $\gamma_{\mathrm{CO} 2}$ is $78.9 \%$ at $8 \mathrm{MPa}$ and $30{ }^{\circ} \mathrm{C}$, and it decreased to $42.1 \%$ at $5 \mathrm{MPa}$ and $90{ }^{\circ} \mathrm{C}$ (Figure $6(\mathrm{c} 1)$ ). Moreover, Figure $6(\mathrm{~d} 1-\mathrm{d} 4)$ show that a decrease in temperature and pressure are beneficial for $\beta_{\mathrm{CO} 2} \cdot \beta_{\mathrm{CO} 2}$ is $83.3 \%$ at $8 \mathrm{MPa}$ and $90{ }^{\circ} \mathrm{C}$, and it increased to $86.7 \%$ when pressure decreased to $5 \mathrm{MPa}$. Moreover, $\beta_{\mathrm{CO} 2}$ increased further to $88.7 \%$ when pressure and temperature were decreased to $5 \mathrm{MPa}$ and $30{ }^{\circ} \mathrm{C}$, respectively (Figure 6(d1)).

Figure 6 shows that an increase in $R$ contributes to an increase in $\gamma_{\mathrm{O} 2}$ and $\beta_{\mathrm{O} 2}$, but decreases the values of $\gamma_{\mathrm{CO} 2}$ and $\beta_{\mathrm{CO} 2} \cdot \gamma_{\mathrm{O} 2}, \beta_{\mathrm{O} 2}, \gamma_{\mathrm{CO} 2}$, and $\beta_{\mathrm{CO} 2}$ at $P=5 \mathrm{MPa}$ and $\mathrm{T}=90{ }^{\circ} \mathrm{C}$ are $92.8 \%, 56.5 \%$, $42.1 \%$, and $88.9 \%$, respectively, at $R=1.5$. $\gamma_{\mathrm{O} 2}$ and $\beta_{\mathrm{O} 2}$ increased to $98.2 \%$ and $78.5 \%$, respectively, whereas $\gamma_{\mathrm{CO} 2}$ and $\beta_{\mathrm{CO} 2}$ decreased to $15.7 \%$ and $75 \%$, respectively, when $R$ increased to 3 . An increase in $R$ increases the amount of oxygen in reactor effluent, whereas the amount of $\mathrm{CO}_{2}$ remains constant (constant (Table 2(A1-A4))). An increase in $R$ is conducive to $\mathrm{OR}$, but reduces $\mathrm{CO}_{2}$ recovery and purity. The optimized parameters are provided in Table 2(A1-A4). pressure range of $6 \mathrm{MPa}$ to $7 \mathrm{MPa}$ and a temperature range of $30^{\circ} \mathrm{C}$ to $40^{\circ} \mathrm{C}$ are appropriate for the high-pressure separator. 


\subsubsection{Feed Concentration}

The effects of pressure and temperature at different feed concentrations on species recovery and purity (Figure $7(\mathrm{a} 1-\mathrm{a} 5, \mathrm{~b} 1-\mathrm{b} 5, \mathrm{c} 1-\mathrm{c} 5, \mathrm{~d} 1-\mathrm{d} 5))$ are similar to those discussed in the previous section. The values of $\gamma_{\mathrm{CO} 2}$ and $\beta_{\mathrm{O} 2}$ will be lower at higher feed concentrations, but the values of $\gamma_{\mathrm{O} 2}$ and $\beta_{\mathrm{CO} 2}$ will be higher. Although an increase in feed concentration will increase the amounts of oxygen and $\mathrm{CO}_{2}$ in the reactor effluent with the same proportion, the solubility difference between oxygen and $\mathrm{CO}_{2}$ in the water achieves the following results. The $\gamma_{\mathrm{O} 2}, \beta_{\mathrm{O} 2}, \gamma_{\mathrm{CO} 2}$, and $\beta_{\mathrm{CO} 2}$ at $P=5 \mathrm{MPa}$ and $\mathrm{T}=90^{\circ} \mathrm{C}$ are $88.9 \%, 80.0 \%, 50.0 \%$, and $66.7 \%$ at $\omega=2 \mathrm{wt} \%$, respectively (Figure $7(\mathrm{a} 1, \mathrm{~b} 1, \mathrm{c} 1, \mathrm{~d} 1)$ ). When $\omega$ increased to $10 \mathrm{wt} \%, \gamma_{\mathrm{O} 2}$ and $\beta_{\mathrm{CO} 2}$ increased to $98.2 \%$ and $85.7 \%$, respectively, but $\beta_{\mathrm{O} 2}$ and $\gamma_{\mathrm{CO} 2}$ decreased to $68.2 \%$ and $19.3 \%$, respectively (Figure $7(\mathrm{a} 5, \mathrm{~b} 5, \mathrm{c} 5, \mathrm{~d} 5)$ ).

Therefore, an increase in feed concentration is also conducive to OR, but oxygen purity will be lower. Moreover, an increase in feed concentration is unfavorable for $\mathrm{CO}_{2}$ recovery, but high $\mathrm{CO}_{2}$ purity will be obtained. The optimized parameters at different feed concentrations are provided in (B1-B4) in Table 2. A pressure range of $5 \mathrm{MPa}$ to $7 \mathrm{MPa}$ and a temperature range of $30^{\circ} \mathrm{C}$ to $70{ }^{\circ} \mathrm{C}$ are appropriate for the high-pressure separator.

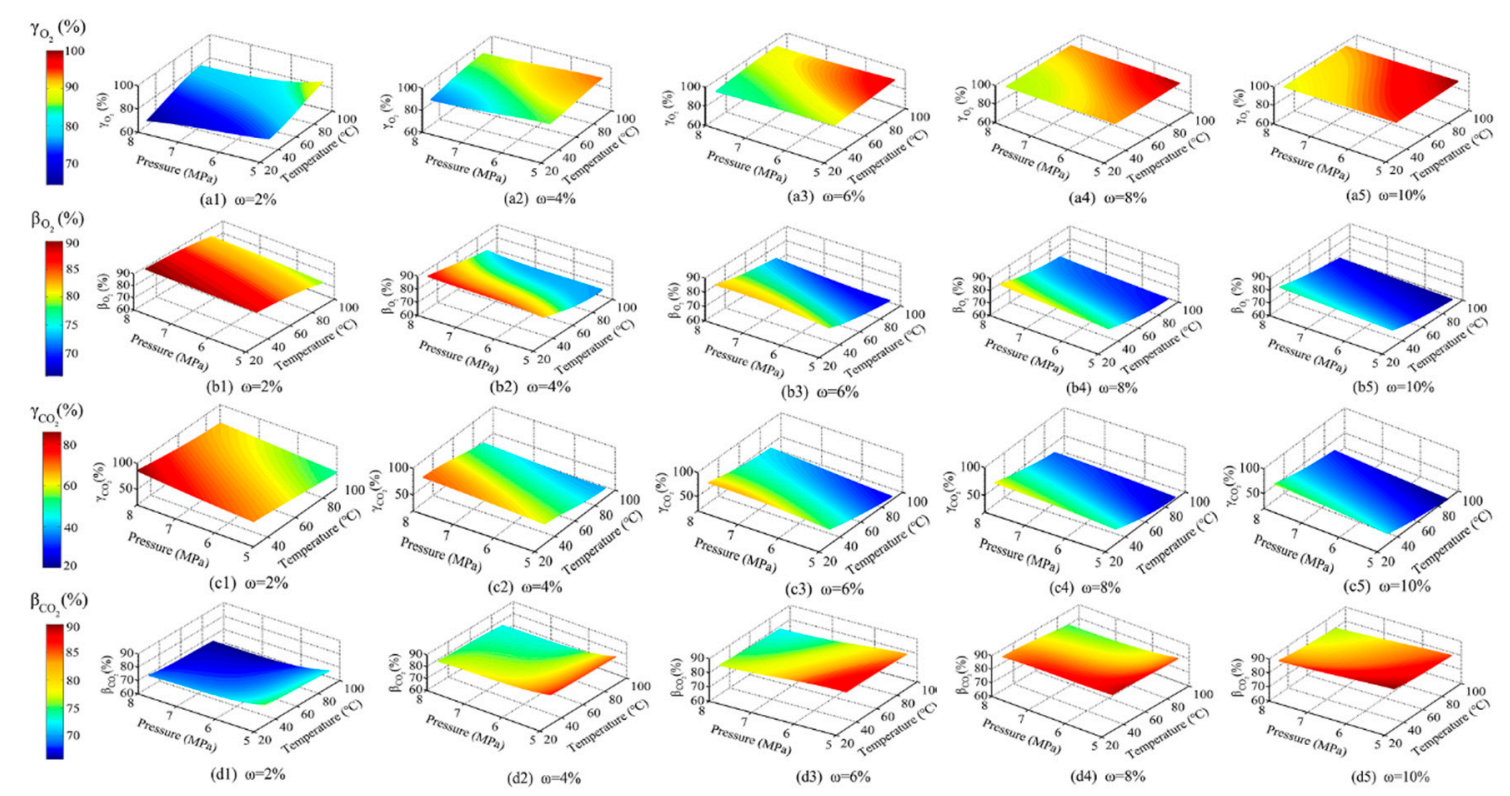

Figure 7. The effect of feed concentration on the performance of the high-pressure and low-pressure separator, (a1) $\gamma_{\mathrm{O} 2}$ at $\omega=2 \mathrm{wt} \%$, (a2) $\gamma_{\mathrm{O} 2}$ at $\omega=4 \mathrm{wt} \%$, (a3) $\gamma_{\mathrm{O} 2}$ at $\omega=6 \mathrm{wt} \%$, (a4) $\gamma_{\mathrm{O} 2}$ at $\omega=8 \mathrm{wt} \%$, (a5) $\gamma_{\mathrm{O} 2}$ at $\omega=10 \mathrm{wt} \%$, (b1) $\beta_{\mathrm{O} 2}$ at $\omega=2 \mathrm{wt} \%,(\mathbf{b} 2) \beta_{\mathrm{O} 2}$ at $\omega=4 \mathrm{wt} \%,(\mathbf{b} 3) \beta_{\mathrm{O} 2}$ at $\omega=6 \mathrm{wt} \%,(\mathbf{b} 4) \beta_{\mathrm{O} 2}$ at $\omega=8 \mathrm{wt} \%$, (b5) $\beta_{\mathrm{O} 2}$ at $\omega=10 \mathrm{wt} \%$, (c1) $\gamma_{\mathrm{CO} 2}$ at $\omega=2 \mathrm{wt} \%,(\mathbf{c} 2) \gamma_{\mathrm{CO} 2}$ at $\omega=4 \mathrm{wt} \%,(\mathrm{c} 3) \gamma_{\mathrm{CO} 2}$ at $\omega=6 \mathrm{wt} \%$, (c4) $\gamma_{\mathrm{CO} 2}$ at $\omega=8 \mathrm{wt} \%$, (cd) $\gamma_{\mathrm{CO} 2}$ at $\omega=10 \mathrm{wt} \%,(\mathbf{d} 1) \beta_{\mathrm{CO} 2}$ at $\omega=2 \mathrm{wt} \%,(\mathbf{d} 2) \beta_{\mathrm{CO} 2}$ at $\omega=4 \mathrm{wt} \%$, (d3) $\beta_{\mathrm{CO} 2}$ at $\omega=6 \mathrm{wt} \%$, (d4) $\beta_{\mathrm{CO} 2}$ at $\omega=8 \mathrm{wt} \%$, and (d5) $\beta_{\mathrm{CO} 2}$ at $\omega=10 \mathrm{wt} \%$. 
Table 2. Detailed parameters of the high-pressure and low-pressure parameters.

\begin{tabular}{|c|c|c|c|c|c|c|c|c|c|c|c|c|c|c|c|c|c|c|c|c|}
\hline & $\mathbf{R}^{\alpha}$ & $\begin{array}{l}\omega^{\beta} \\
(w t \%)\end{array}$ & $\begin{array}{c}F_{\mathrm{O}_{2}} \\
\left(\mathrm{~kg} \cdot \mathrm{h}^{-1}\right)\end{array}$ & $\begin{array}{c}F_{\mathrm{CO}_{2}^{\gamma}}^{\gamma} \\
\left(\mathrm{kg} \cdot \mathrm{h}^{-1}\right)\end{array}$ & $\begin{array}{c}F_{\mathrm{H} 2 \mathrm{O}^{\delta}} \\
\left(\mathrm{kg} \cdot \mathrm{h}^{-1}\right)\end{array}$ & $\begin{array}{c}P^{\prime} \\
/ \mathrm{MPa}\end{array}$ & $\begin{array}{c}T^{\prime} \\
\left({ }^{\circ} \mathrm{C}\right)\end{array}$ & $\begin{array}{c}F^{\prime} \mathrm{O} 2, \mathrm{~g} \\
\left(\mathrm{~kg} \cdot \mathrm{h}^{-1}\right)\end{array}$ & $\begin{array}{r}F^{\prime} \mathrm{CO}_{2, g} \\
\left(\mathrm{~kg} \cdot \mathrm{h}^{-1}\right)\end{array}$ & $\begin{array}{l}F^{\prime} \mathrm{H}^{2 \mathrm{O}, \mathrm{g}} \\
\left(\mathrm{kg} \cdot \mathrm{h}^{-1}\right)\end{array}$ & $\begin{array}{l}\gamma_{02} \\
(\%)\end{array}$ & $\begin{array}{l}\beta_{\mathrm{O} 2} \\
(\%)\end{array}$ & $\begin{array}{c}P^{\prime \prime} \\
/ \mathrm{MPa}\end{array}$ & $\begin{array}{c}T^{\prime \prime} \\
\left({ }^{\circ} \mathrm{C}\right)\end{array}$ & $\begin{array}{c}F^{\prime} \mathrm{CO}_{2,1} \\
\left(\mathrm{~kg} \cdot \mathrm{h}^{-1}\right)\end{array}$ & $\begin{array}{c}F^{\prime} \mathrm{O} 2,1 \\
\left(\mathrm{~kg} \cdot \mathrm{h}^{-1}\right)\end{array}$ & $\begin{array}{c}F^{\prime \prime} \mathrm{o}, \mathrm{g} \\
\left(\mathrm{kg} \cdot \mathrm{h}^{-1}\right)\end{array}$ & $\begin{array}{l}F^{\prime \prime} \mathrm{CO} 2, \mathrm{~g} \\
\left(\mathrm{~kg} \cdot \mathrm{h}^{-1}\right)\end{array}$ & $\begin{array}{c}\gamma_{\mathrm{CO} 2} \\
(\%)\end{array}$ & $\begin{array}{c}\beta_{\mathrm{CO} 2} \\
(\%)\end{array}$ \\
\hline A1 & 1.5 & 6 & 0.450 & 0.825 & 37.820 & $6-7$ & $30-40$ & $0.353-0.385$ & $0.122-0.21$ & $<0.018$ & $78.6-85.7$ & $70.6-78.6$ & 0.1 & 20 & $0.616-0.704$ & $0.064-0.096$ & $0.064-0.096$ & $0.572-0.616$ & 73.68 & $1-87.5$ \\
\hline $\mathrm{A} 2^{\varepsilon}$ & 2. & 6 & & & & $6-$ & & & & & & & & & & & & & & \\
\hline A3 & 2.5 & 6 & & & & $6-$ & & & & & & & & & & & & & & $76-81.1$ \\
\hline A4 & 3.0 & 6 & & & & $6-7$ & & & & & & & & & & & & & & 73-80 \\
\hline B1 & 2 & 2 & & & & - & & & & & 78 & & 0.1 & 20 & & & & & & $75-80$ \\
\hline B2 & 2. & 4 & & & & 6 & & 0. & & & 89.5 & $81-$ & 0.1 & 20 & & 0.064 & 0.064 & 0.352 & $64.58-69.23$ & $80-82$ \\
\hline B3 & 2.0 & 6 & & & & 6-7 & & 832 & 0. & $<0.018$ & $89.3-92.86$ & $76.5-80.6$ & 0 & 20 & 72 & $0.064-0.096$ & $0.064-0.096$ & 0.44 & $52.63-63.16$ & $80-84.62$ \\
\hline B4 & 2. & 8 & & & & $6-8$ & & & & & 92.1 & & 0. & 20 & & 96 & 6 & 66 & .00 & 81.2 \\
\hline B5 & 2.0 & 10 & 1.500 & 1.375 & 43.670 & $6-8$ & $30-40$ & $1.408-1.420$ & $0.582-0.758$ & $<0.018$ & $93.62-95.7$ & $73-77.2$ & 0.1 & 20 & $0.616-0.792$ & $0.064-0.096$ & $0.064-0.096$ & $0.572-0.748$ & $41.93-54.84$ & $82.4-88.2$ \\
\hline
\end{tabular}

${ }^{\alpha}$ The stoichiometric oxygen excess at the reactor inlet ${ }^{\beta}$ the feed concentration at the reactor inlet, and corresponding feed flow $F_{\mathrm{f}}$ is $10 \mathrm{~kg} \cdot \mathrm{h}^{-1} \gamma \mathrm{\gamma}$ the oxygen $\left(F_{\mathrm{O} 2}\right)$ and carbon dioxide $\left(F_{\mathrm{CO} 2}\right)$ flows at the reactor outlet were calculated from the completed oxidation of methanol based on the parameters of the reactor inlet. ${ }^{\delta}$ the water flow $\left(F_{\mathrm{H} 2 \mathrm{O}}\right)$ at the reactor outlet was originated from the injection of transpiring water with a transpiring intensity of 0.06 [13] and methanol oxidation product. ${ }^{\varepsilon} \mathrm{A} 2=\mathrm{B} 3$. 


\section{Aspen Model for SCWO System Simulation with Energy and Species Recovery}

In this section, our pilot plant was amplified similar to an SCWO industrial plant with a treatment capacity of $1000 \mathrm{~kg} / \mathrm{h}$ based on the optimized parameters for energy and species recovery. The simulation process can be established without considering the complex equipment structure in Aspen Plus, which is a 1D simulation software based on mass and energy conservation.

\subsection{TWR}

A TWR is the most important equipment of an SCWO system, and Figure 8a shows the diagram of the TWR in our pilot plant [13]. Five streams were introduced into the reactor. The oxygen and the feed were injected into the reactor via a coaxial nozzle from the top of the reactor, with oxygen in the central tube and the feed in the outer tube. The transpiring tube is divided into three zones using two retaining rings to ensure that the transpiring streams can pass through the porous tube at different temperatures and flow rates. The transpiring water $(\mathrm{t} w)$ is divided into three branches, namely, the upper (tw1), middle (tw2), and lower (tw3) branches of transpiring water.

Considering the complicated flow, transpiring heat, and reaction characteristics, the reactor was separated into three sections for simplicity, namely, the mixing, adiabatic reacting, and cooling sections. A simplified model was proposed to simulate the TWR (Figure 8b) in Aspen Plus. The mixing section provides a sufficient mixing space for the reactants. Among the three branches of transpiring water, the upper branch is the only one that can directly influence the reaction [11]. For simplicity, the feed, oxygen, and upper branch of transpiring water will first flow into a mixer to fully mix the reactants. The adiabatic reacting section is simulated by a plug flow reactor (PLUG). When reaction is done, the product flows into the cooling section where the middle and lower branches of transpiring water are injected sequentially into the reactor, and the two mixers are used to simulate the mixing process. Finally, hot effluent flows out of the reactor.

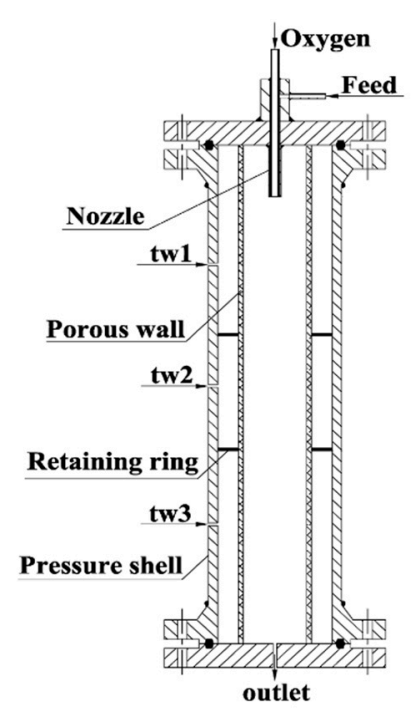

(a)

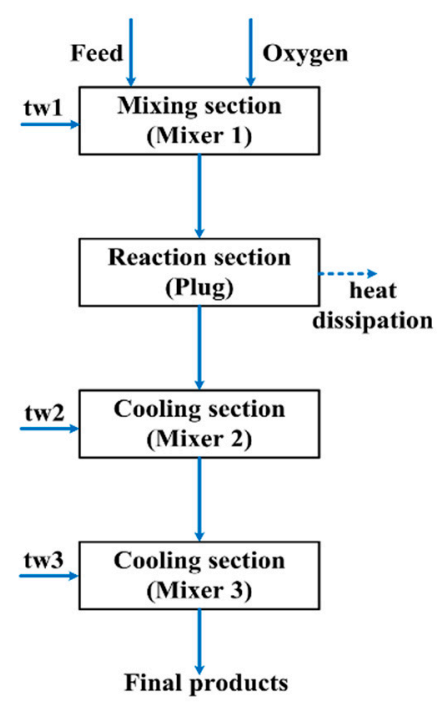

(b)

Figure 8. (a) The experimental diagram of the TWR and (b) the simplified model for the TWR in Aspen plus.

\subsection{Reaction}

A desalinated water-methanol mixture is also used as artificial wastewater in Aspen Plus. Previous experimental results $[13,32]$ have proven that $\mathrm{CO}$ is the major intermediate during the 
SCWO of methanol. Thus, a two-step mechanism based on Arrhenius law is created and implemented in the simulation, as shown in Equations (6) to (9):

$$
\begin{gathered}
\mathrm{CH}_{3} \mathrm{OH}+\mathrm{O}_{2}=\mathrm{CO}+\mathrm{H}_{2} \mathrm{O} \\
\mathrm{CO}+0.5 \mathrm{O}_{2}=\mathrm{CO}_{2} \\
r_{\mathrm{CH}_{3} \mathrm{OH}}=-\frac{\mathrm{d}\left[\mathrm{CH}_{3} \mathrm{OH}\right]}{\mathrm{d} t}=2.0 \times 10^{21} \times \exp \left(\frac{-303.85 \mathrm{~kJ} / \mathrm{mol}}{\mathrm{RT}}\right)\left[\mathrm{CH}_{3} \mathrm{OH}\right] \\
r_{\mathrm{CO}}=-\frac{\mathrm{d}[\mathrm{CO}]}{\mathrm{d} t}=3.16 \times 10^{6} \times \exp \left(\frac{-88 \mathrm{~kJ} / \mathrm{mol}}{\mathrm{RT}}\right)[\mathrm{CO}]
\end{gathered}
$$

The kinetic data used in the present study were based on the literature [33-36], and the reaction order of oxygen was assumed zero because of the large excess amount.

\subsection{Process Flow}

The simulation process, including energy recovery and OR, was developed and presented in Figure 9. After the feed is pressurized by pump 1 (P1), it first flows into heat exchanger 1 (HE1) to be heated by one branch of the final products (FINAL), and then it flows into electric heater 1 (EH1) for further heating. Simultaneously, oxygen is pressurized by the air compressor (AC), and then flows into mixer 1 (M1) to fully mix with the feed and tw1. After transpiring water is pressurized by pump 2 (P2), it splits into three branches (tw1, tw2, and tw3). Before tw1 reaches M1, it first flows into heat exchanger 2 (HE2) to be preheated, and then flows to electric heater 2 (EH2) for further heating. tw2 is preheated by heat exchanger 3 (HE3), and then it mixes with the effluent in mixer 2 (M2). tw3 mixes with the effluent in mixer 3 (M3) to form the final products (FINAL). Oxygen and tw3 are injected into the reactor at room temperature.

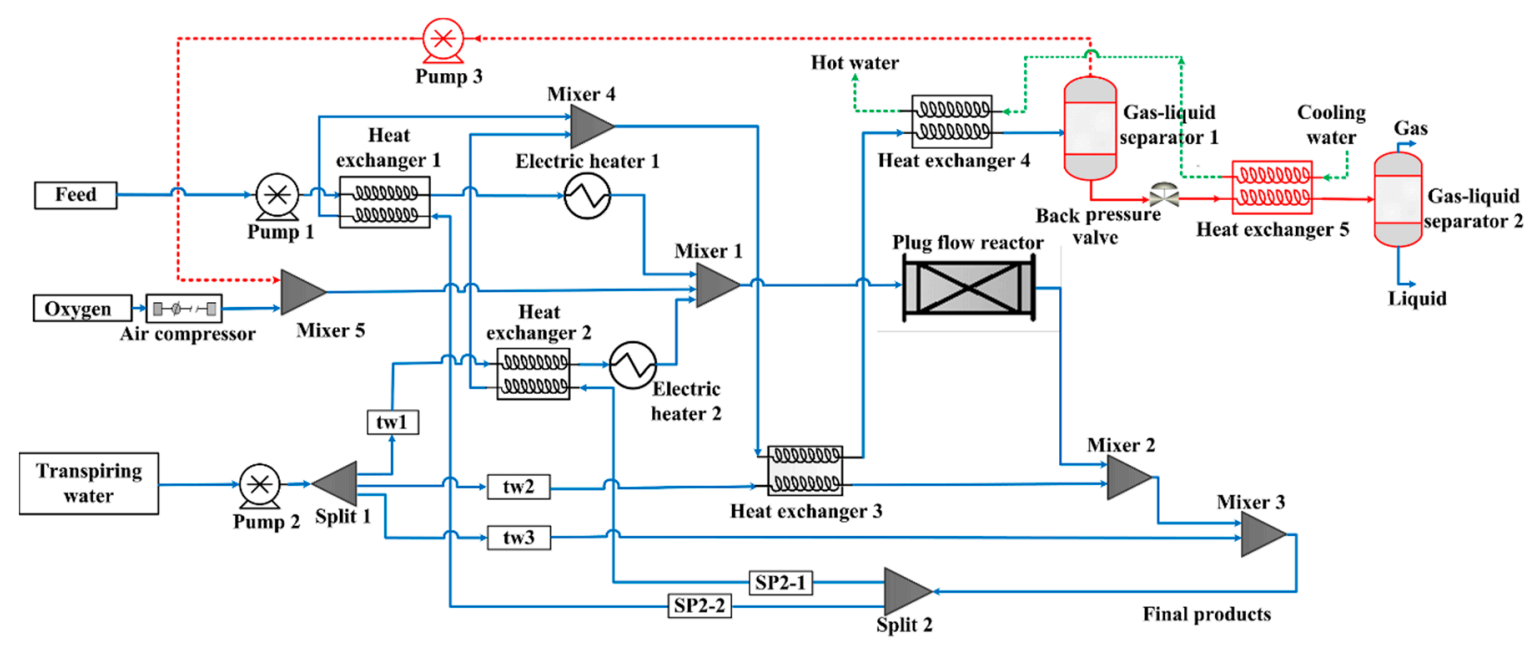

Figure 9. The Aspen Plus diagram of supercritical water oxidation system with oxygen recovery (lines and equipment with red color are specially for OR).

FINAL is split into two branches in split 2, and these branches are treated as hot streams to preheat the feed and tw1. The two branches of FINAL then reunite in mixer 4 (M4) and are cooled down in heat exchanger 3 (HE3). Moreover, the effluent was further cooled in heat exchangers 4 (HE4) and 5 (HE5) by cooling water before gas-liquid separators 1 (S1) and 2 (S2), respectively. The recovered oxygen from $\mathrm{S} 1$ is pressurized by pump 3 (P3) and mixed with the supplement oxygen in mixer 5 (M5). 


\section{Energy and Economic Analysis}

\subsection{Equipment Investment Calculation}

Several alternatives are available to estimate the cost of a major piece of equipment, such as obtaining a quotation from a suitable vendor, using the cost data of a previously purchased equipment of the same type, or utilizing available summary graphs for various types of common equipment. Considering that no similar SCWO industrial plant exists, the last option may be more accurate for our preliminary cost estimation. This methodology allows the estimation of equipment and installation costs according to certain base conditions (e.g., low pressure and construction materials with the lowest cost) and a particular year. Deviations from the base conditions are corrected by a factor that depends on working pressure and construction materials. The obtained cost is then translated into the current time by using an index that considers the time variation of equipment cost.

On the basis of the results obtained for the pilot plant under typical conditions (Table 3, B3, and D3), economic analyses for the $1000 \mathrm{~kg} / \mathrm{h} \mathrm{SCWO}$ plant with and without OR were performed. The investment costs for the TWR, high-pressure pumps, compressors, electric heaters, and gas-liquid separators can be calculated as follows [37]:

$$
\begin{gathered}
C_{\mathrm{PM}}=C\left(B_{1}+B_{2} F_{\mathrm{M}} F_{\mathrm{P}}\right) \\
\lg C=K_{1}+K_{2} \lg X+K_{3}(\lg X)^{2} \\
\lg F_{\mathrm{P}}=C_{1}+C_{2} \lg P+C_{3}(\lg P)^{2}
\end{gathered}
$$

where $C$ is the equipment investment that uses carbon steel under environmental conditions, and $X$ is the design parameter (e.g., pump power and reactor volume). $P$ is the design pressure, which is set as $30 \mathrm{MPa}$. $K_{1}, K_{2}, K_{3}, C_{1}, C_{2}, C_{3}, B_{1}$, and $B_{2}$ are constant for each piece of equipment. $F_{\mathrm{P}}$ and $F_{\mathrm{M}}$ are the pressure and material correction coefficients, respectively. Detailed data are provided in Table 4. 
Table 3. The operating parameters for the SCWO systems with and without oxygen recovery.

\begin{tabular}{|c|c|c|c|c|c|c|c|c|c|c|c|c|c|c|c|c|c|c|c|c|c|c|c|c|c|c|c|c|c|c|c|c|}
\hline & NO & R & $\begin{array}{c}\omega \\
\text { (wt\%) }\end{array}$ & $\begin{array}{c}F_{\mathrm{f}} \\
\text { (kg. h- }\end{array}$ & 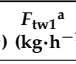 & $\begin{array}{l}F_{\mathrm{tw} w 2} \\
\mathrm{~kg} \cdot \mathrm{h}\end{array}$ & $\begin{array}{l}F_{\mathrm{tw} w} \\
\mathrm{~kg} \cdot \mathrm{h}^{-}\end{array}$ & $\begin{array}{l}F_{\mathrm{Cw}^{\mathrm{b}}}^{\mathrm{b}} \\
\left.\mathrm{kg} \cdot \mathrm{h}^{-1}\right)\end{array}$ & $\begin{array}{l}F_{\text {Final }} \\
\left(\mathrm{kg}^{\prime} \cdot \mathbf{h}^{-1}\right)\end{array}$ & $\begin{array}{l}\left.F_{F_{\mathrm{pp} 2-2} \mathrm{c}^{2}}\right)\left(\mathrm{kgg} \cdot \mathrm{h}^{-1}\right. \\
\end{array}$ & $\begin{array}{c}F_{\mathrm{sp} 2-2} \\
\text { (kg-h-1) }\end{array}$ & $\begin{array}{l}F_{\mathrm{O} 2,2 \text { to }} \\
\left(\mathrm{kgg}-\mathrm{h}^{-1}\right.\end{array}$ & 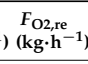 & $\begin{array}{l}F_{\mathrm{O}, 2, \mathrm{su}} \\
\left(\mathrm{kg}, \mathrm{h}^{-1}\right.\end{array}$ & $\begin{array}{l}F_{\mathrm{CO} 2, \mathrm{re}} \\
\text { 1) } \\
\left(\mathrm{kg} \cdot \mathrm{h}^{-1}\right)\end{array}$ & 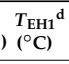 & $\begin{array}{l}T_{\mathrm{EH} 2} \\
\left({ }^{\circ} \mathrm{C}\right) \\
\end{array}$ & $\begin{array}{l}T_{\text {EH3 }} \\
\left({ }^{\circ} \mathrm{C}\right) \\
\end{array}$ & $\begin{array}{c}T_{\mathrm{f}} \\
\left({ }^{\circ} \mathrm{C}\right) \\
\end{array}$ & $\begin{array}{ll}T_{\mathrm{tw} 1} \\
\left({ }^{\circ} \mathrm{C}\right) \\
\end{array}$ & $\begin{array}{l}T_{\mathrm{tw} 2} \\
\left({ }^{\circ} \mathrm{C}\right) \\
\end{array}$ & $\begin{array}{ll}T_{\mathrm{M} 1} \\
\left({ }^{\circ} \mathrm{C}\right) \\
\end{array}$ & $\begin{array}{ll}T_{\text {out }} \\
\left({ }^{\circ} \mathrm{C}\right) \\
\end{array}$ & $\begin{array}{l}T_{\text {sp2-1 }} \\
\left({ }^{\circ} \mathrm{C}\right) \\
\end{array}$ & $\begin{array}{l}T_{\text {sp2-2 }} \\
\left({ }^{\circ} \mathrm{C}\right) \\
\end{array}$ & $\begin{array}{l}T_{\mathrm{M} 4} \\
\left({ }^{\circ} \mathrm{C}\right) \\
\end{array}$ & $\begin{array}{l}\mathrm{CO}_{\text {out }} \\
(\%)\end{array}$ & $\begin{array}{l}\mathrm{TOC}_{\text {out }} \\
\text { /ppm }\end{array}$ & $\begin{array}{l}\gamma_{0} \\
(\%)\end{array}$ & $\begin{array}{l}\gamma_{\mathrm{CO} 2} \\
(\%)\end{array}$ & $\begin{array}{l}\beta_{\mathrm{O} 2} \\
(\%) \\
\end{array}$ & $\begin{array}{l}\beta_{\mathrm{CO} 2} \\
(\%)\end{array}$ \\
\hline \multirow{7}{*}{$\begin{array}{l}\text { With } \\
\text { oxygen } \\
\text { recovery }\end{array}$} & $\mathrm{A} 1$ & 1.5 & 6 & 1000 & $\begin{array}{l}1857 \\
1931\end{array}$ & 620 & 1236 & $\begin{array}{l}19,700 \\
\end{array}$ & 4927 & $\begin{array}{l}2956 \\
2072\end{array}$ & 1970 & 135 & 35.8 & $\begin{array}{l}99.2 \\
990\end{array}$ & $\begin{array}{l}79.2 \\
792\end{array}$ & 301 & 301 & 181 & 380 & 350 & 160 & 360 & 333 & 191 & 223 & 204 & 0 & 0 & 79.56 & 73.7 & 73.89 & 86.78 \\
\hline & A3 & 25 & 6 & 101 & 19 & 64 & & $\begin{array}{l}20,000 \\
20250\end{array}$ & $\begin{aligned} 51 \\
53\end{aligned}$ & $\begin{array}{l}3072 \\
3185\end{array}$ & 20 & $\begin{array}{l}180 \\
225\end{array}$ & $\begin{array}{l}82.1 \\
\end{array}$ & $\begin{array}{l}97.9 \\
\end{array}$ & 7 & 300 & 300 & & 30 & & 15 & & 330 & 188 & $\begin{array}{l}220 \\
220\end{array}$ & & 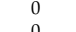 & 0 & $\begin{array}{l}91.22 \\
02.4\end{array}$ & & 77.89 & 82.13 \\
\hline & $\begin{array}{l}\mathrm{A} 3 \\
\mathrm{~A} 4\end{array}$ & $\begin{array}{l}2.5 \\
3\end{array}$ & $\begin{array}{l}6 \\
6\end{array}$ & $\begin{array}{l}1000 \\
1000\end{array}$ & $\begin{array}{l}2005 \\
2078\end{array}$ & $\begin{array}{l}668 \\
693\end{array}$ & $\begin{array}{l}1336 \\
1385\end{array}$ & $\begin{array}{l}20,030 \\
20,500\end{array}$ & $\begin{array}{l}5308 \\
5500\end{array}$ & $\begin{array}{l}\begin{array}{l}3180 \\
3300\end{array} \\
3\end{array}$ & $\begin{array}{l}2123 \\
2200\end{array}$ & $\begin{array}{l}225 \\
270\end{array}$ & $\begin{array}{l}124.8 \\
169.95\end{array}$ & $\begin{array}{l}100.2 \\
100.05\end{array}$ & $\begin{array}{l}74.8 \\
74.8\end{array}$ & 298 & $\begin{array}{l}299 \\
298\end{array}$ & $\begin{array}{l}179 \\
178\end{array}$ & $\begin{array}{l}381 \\
382\end{array}$ & $\begin{array}{l}350 \\
350\end{array}$ & $\begin{array}{l}158 \\
161\end{array}$ & & $\begin{array}{l}330 \\
328\end{array}$ & $\begin{array}{l}189 \\
190\end{array}$ & 221 & $\begin{array}{l}202 \\
203\end{array}$ & $\begin{array}{l}0 \\
0 \\
0\end{array}$ & $\begin{array}{l}0 \\
0\end{array}$ & $\begin{array}{l}92.44 \\
94.42\end{array}$ & 4 & 84.39 & $\begin{array}{l}78.89 \\
74.56\end{array}$ \\
\hline & B1 & 2 & 2 & & 173 & 578 & & & 4551 & 27 & & & 20. & 39.3 & - & & 296 & & & & & & 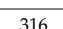 & & & 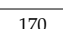 & & 0 & & & & 8021 \\
\hline & & & & & & & & & & & & & & & & & & & & & & & & & & & & & & & & \\
\hline & B3 & 2 & 6 & & & 644 & & & & & & 18 & & 97.9 & & 300 & & 17 & & & & & & & & & & 0 & & & 89 & .13 \\
\hline & B4 & 2 & 8 & 1000 & 2029 & 676 & 1353 & 21,500 & 5399 & 3239 & 2160 & 240 & 113.64 & 126.36 & 101.2 & 303 & 302 & 194 & 376 & 350 & 167 & 352 & 335 & 198 & 236 & 214 & 0 & 0 & 94.7 & 52.1 & 76.20 & 84.36 \\
\hline \multirow{8}{*}{$\begin{array}{l}\text { Without } \\
\text { oxygen } \\
\text { recovery }\end{array}$} & C1 & 1.5 & 0 & & & & & & & & & & & & & & & & & & & & & & & & 0 & 0 & & & & \\
\hline & C & & 6 & & & & & & & & & & - & - & & & & & & & & & & & & & & & - & - & - & - \\
\hline & C3 & 2.5 & 6 & & & & & & & & & & 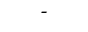 & - & & & & & & & & & & & & & & 0 & 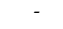 & - & & - \\
\hline & C4 & 3 & 6 & 1000 & 2078 & 693 & 1385 & 21,500 & 5426 & 3255 & 2170 & 270 & - & - & - & 298 & 298 & 180 & 382 & 350 & 161 & 354 & 330 & 190 & 222 & 203 & 0 & 0 & - & - & - & - \\
\hline & D1 & 2 & 2 & & & & & & 45 & & $\begin{array}{l}18 \\
19\end{array}$ & 6 & & & & 297 & & & & & & & & & 183 & & 0 & 0 & & & & \\
\hline & D & 2 & & & & & & & & & & & & & & & & & & & & & & & & & & & & - & & - \\
\hline & D3 & 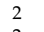 & 6 & & & 644 & & & & & & 180 & & . & & 300 & & & & & & & & & & & & 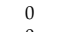 & - & 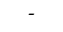 & & - \\
\hline & D4 & 2 & 8 & 1000 & 2029 & 676 & 1353 & 22,500 & 5298 & 3179 & 2119 & 240 & & & & 302 & 302 & 195 & 376 & 350 & 168 & 354 & 337 & 199 & 237 & 215 & 0 & 0 & & 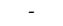 & & - \\
\hline
\end{tabular}

${ }^{a} F_{\mathrm{tw} 1}, F_{\mathrm{tw} 2}$, and $F_{\mathrm{tw} 3}$ are the mass flows for $\mathrm{tw} 1, \mathrm{tw} 2$, and $\mathrm{tw} 3$, respectively. $F_{\mathrm{cw}}$, and $F_{\text {Final }}$ are the mass flows for cooling water and the effluent from the reactor outlet, respectively. $F_{\mathrm{O} 2 \text {,tot }}$ and $F_{\mathrm{O} 2, \mathrm{su}}$ are the mass flows for total oxygen and supplemental oxygen, respectively. $F_{\mathrm{O} 2 \text {,re }}$, and $F_{\mathrm{CO} 2 \text {,re }}$ are the mass flows recovered from the $\mathrm{S} 1$, respectively. ${ }^{\mathrm{b}}$ The outlet temperature of the cooling water is set as $60^{\circ} \mathrm{C}$ by adjusting flow for hot water production. ${ }^{\mathrm{c}}$ The $\mathrm{F}_{\mathrm{SP2} 2-1} / \mathrm{F}_{\mathrm{SP2} 2-2}$ is kept at 1.5 for energy recovery optimization [24]. ${ }^{\mathrm{d}} T_{\mathrm{EH} 1}, T_{\mathrm{EH} 2}$, and $T_{\mathrm{EH} 3}$ are the outlet temperatures of feed, tw1, and tw2 in EH1, EH2, and EH3, respectively. $T_{\mathrm{tw} 1}, T_{\mathrm{f}}$, and $T_{\mathrm{tw} 2}$ are the reactor inlet temperatures for tw1, feed, and tw2, respectively. $T_{\text {out }}$ is the temperatures of the reactor effluent. $T_{\mathrm{SP} 2-1}$, and $T_{\mathrm{SP} 2-2}$ are the temperatures of the reactor effluent after cooling by HE2 and HE1, respectively. $T_{\mathrm{M} 1}$, and $T_{\mathrm{M} 4}$ are the mixing temperatures after M1 and M4, respectively. ${ }^{\mathrm{e}} \mathrm{A} 2=\mathrm{B} 3, \mathrm{C} 2=\mathrm{D} 3 .{ }^{\mathrm{f}}$ The $T_{\mathrm{w}}$ for reaction initiation is usually higher $\left(380-420{ }^{\circ} \mathrm{C}\right)$ than that of the steady state for reaction heat releasing. 
Table 4. The coefficient for each equipment.

\begin{tabular}{ccccccccccc}
\hline Equipment & $\boldsymbol{K}_{\mathbf{1}}$ & $\boldsymbol{K}_{\mathbf{2}}$ & $\boldsymbol{K}_{\mathbf{3}}$ & $\boldsymbol{C}_{\mathbf{1}}$ & $\boldsymbol{C}_{\mathbf{2}}$ & $\boldsymbol{C}_{\mathbf{3}}$ & $\boldsymbol{B}_{\mathbf{1}}$ & $\boldsymbol{B}_{\mathbf{2}}$ & $\boldsymbol{F}_{\mathbf{P}}$ & $\boldsymbol{F}_{\mathbf{M}}$ \\
\hline Reactor & 4.7116 & 0.4479 & 0.0004 & - & - & - & - & - & - & 4 \\
Pump & 3.8696 & 0.3161 & 0.1220 & -0.3935 & 0.3957 & -0.0023 & 1.89 & 1.35 & 2.2 & - \\
Electric heater & 1.1979 & 1.4782 & -0.0958 & -0.01635 & 0.05687 & -0.00876 & - & - & - & 1.4 \\
Compressor & 2.2897 & 1.3604 & -0.1027 & 0 & 0 & 0 & - & - & 2.2 & - \\
Gas-liquid separator & 3.4974 & 0.4485 & 0.1074 & - & - & - & 1.49 & 1.52 & - & 1.25 \\
\hline
\end{tabular}

Directly estimating the cost of the TWR is difficult because no similar reactor is available for comparison. The cost of a plug flow reactor was first estimated with the same volume for sufficient residence time, and then the cost of the TWR was calculated based on our empirical relationship. The reactor was divided into three sections according to our previous TWR design [24]. The total required volume of the reactor is $570 \mathrm{~L}$. Thus, the actual reactor volume is $695 \mathrm{~L}$ when a loading coefficient of 0.82 is considered [38].

Shell and tube heat exchangers were selected in the SCWO system, and the cost of the regular heat exchanger can be calculated as follows [39]:

$$
\mathrm{C}_{\mathrm{HE}}=3.28 \times 10^{4}\left(\frac{A}{80}\right)^{0.68} \delta_{\mathrm{M}} \delta_{\mathrm{P}} \delta_{\mathrm{T}}
$$

where $A$ is the heat exchanger area. Considering that the heat exchanger was used in high-pressure and high-temperature conditions, $\delta_{\mathrm{M}}, \delta_{\mathrm{P}}$, and $\delta_{\mathrm{T}}$ are the material, pressure, and temperature correction coefficients (Table 5), respectively, which were used to modify cost estimation.

Table 5. The coefficients for heat exchanger.

\begin{tabular}{ccccccc}
\hline Equipment & Temperature $\left({ }^{\circ} \mathbf{C}\right)$ & Pressure (MPa) & Material & $\delta_{\mathbf{M}}$ & $\delta_{\mathbf{P}}$ & $\delta_{\mathbf{T}}$ \\
\hline Heat exchanger 1 & 500 & 30 & Stainless steel 316L & 2.9 & 1.9 & 2.1 \\
Heat exchanger 2 & 500 & 30 & Stainless steel 316L & 2.9 & 1.9 & 2.1 \\
Heat exchanger 3 & 500 & 30 & Stainless steel 316L & 2.9 & 1.9 & 2.1 \\
Heat exchanger 4 & 300 & 30 & Stainless steel 316L & 2.9 & 1.9 & 1.6 \\
\hline
\end{tabular}

The obtained cost is then translated into the present time by using an index that considers the time variation of equipment cost for the process industries, which was calculated using the following equation [37]:

$$
\text { Cost }_{2016}=\text { Cost }_{2001}\left(\frac{C E P C I_{2016}}{C E P C I_{2001}}\right)
$$

Given the aforementioned considerations, the total equipment cost for the SCWO pilot plant with and without OR in 2016 was calculated as $\$ 2,592,096$ and $\$ 2,522,654$, respectively. Details on equipment sizing assumptions, construction materials, and estimated cost per piece of equipment are presented in Table 6. 
Table 6. Equipment investment.

\begin{tabular}{|c|c|c|c|c|c|c|c|c|c|c|}
\hline \multirow{2}{*}{ NO } & \multirow{2}{*}{ Equipment } & \multirow{2}{*}{ Parameter } & \multicolumn{4}{|c|}{ SCWO System with Oxygen Recovery } & \multicolumn{4}{|c|}{ SCWO without Oxygen Recovery } \\
\hline & & & Theoretical Value & Safety Factor ${ }^{a}$ & Design Value & Cost (\$) & Theoretical Value & Safety Factor ${ }^{a}$ & Design Value & Cost $(\$)$ \\
\hline 1 & Heat exchanger 1 & Area $/ \mathrm{m}^{2}$ & 5.77 & 1.2 & 7 & 72,412 & 5.76 & 1.2 & 7 & 72,412 \\
\hline 2 & Heat exchanger 2 & Area $/ \mathrm{m}^{2}$ & 12.26 & 1.2 & 15 & 121,586 & 12.24 & 1.2 & 15 & 121,586 \\
\hline 3 & Heat exchanger 3 & Area $/ \mathrm{m}^{2}$ & 1.146 & 1.2 & 1.5 & 25,403 & 1.14 & 1.2 & 1.5 & 25,403 \\
\hline 4 & Heat exchanger 4 & Area $/ \mathrm{m}^{2}$ & 19.73 & 1.2 & 24 & 127,522 & 22.5 & 1.2 & 27 & 143,166 \\
\hline 5 & Heat exchanger 5 & Area $/ \mathrm{m}^{2}$ & 3.78 & 1.2 & 4.5 & 25,533 & - & - & - & - \\
\hline 6 & Waste water pump & Power $/ \mathrm{kW}$ & 11.28 & 1.2 & 14 & 155,452 & 11.28 & 1.2 & 14 & 155,452 \\
\hline 7 & Compressor $^{b}$ & Power/kW & 36.88 & 1.6 & 60 & 132,840 & 36.88 & 1.6 & 60 & 132,840 \\
\hline 8 & Transpiring water pump & Power/kW & 41.32 & 1.2 & 50 & 145,800 & 41.32 & 1.2 & 50 & 145,800 \\
\hline 9 & Oxygen circulation pump & Power/kW & 4.59 & 2.1 & 9.5 & 21,034 & - & - & - & - \\
\hline 10 & Transpiring wall reactor & Volume $/ \mathrm{m}^{3}$ & 0.695 & 3 & 2.1 & 531,798 & 0.695 & 3 & 2.1 & 531,798 \\
\hline 11 & High-pressure separator & Volume $/ \mathrm{m}^{3}$ & 0.189 & 3 & 0.6 & 7142 & - & - & - & - \\
\hline 12 & Low-pressure separator & Volume $/ \mathrm{m}^{3}$ & 0.186 & 1.5 & 0.3 & 3570 & 0.189 & 1.5 & 0.3 & 3570 \\
\hline 13 & Electric heater 1 & Power/kW & 306.81 & 1.2 & 370 & 31,365 & 306.81 & 1.2 & 370 & 31,365 \\
\hline 14 & Electric heater 2 & Power/kW & 190.56 & 1.2 & 228 & 19,380 & 190.56 & 1.2 & 228 & 19,380 \\
\hline 15 & Total equipment cost/1996 & $\$$ & & $1,420,837$ & & & & $1,382,772$ & & \\
\hline 16 & Total equipment cost/2016 & $\$$ & & $2,253,997$ & & & & $2,193,612$ & & \\
\hline 17 & Installation $\operatorname{cost}^{\mathrm{c}}$ & $\$$ & & 338,099 & & & & 329,042 & & \\
\hline 18 & Total investment cost/2016 & $\$$ & & $2,592,096$ & & & & $2,522,654$ & & \\
\hline
\end{tabular}

${ }^{a}$ obtained from reference [38]. ${ }^{b}$ based on the power consumption in the system startup. ${ }^{c}$ set as $15 \%$ of the equipment cost. 


\subsection{Treatment Cost Calculation and Distribution}

The treatment cost of an SCWO system includes investment and operating costs. The basic operating costs were determined using the procedure parameters in Table 3 (B3) and (D3), which were estimated under the assumption that the plant operates 330 days a year and $24 \mathrm{~h}$ a day. The operating cost includes energy consumption, raw material, labor, and capital-related costs [36]. Energy consumption cost includes the cost of electricity required to operate the process equipment and the plant. Raw material cost, which includes the costs of oxygen, cooling water, and transpiring water, was estimated from the amount of required raw materials. Labor cost includes the salaries of operation and supervisory employees. The depreciation time of the system is 10 years, and the maintenance cost is $3 \%$ of the equipment cost.

Figure 10 shows the treatment cost comparisons of the SCWO systems with and without OR. In the SCWO system without OR, electricity, depreciation, and oxygen contribute to the primary treatment cost, accounting for 46.18, 30.24, and 18.01 \$.t $\mathrm{t}^{-1}$, respectively, of the total cost. Although the heat of the reactor effluent has been recovered, energy (electricity) consumption remains high. This phenomenon is attributed to the low-grade heat of the reaction effluent $\left(<370{ }^{\circ} \mathrm{C}\right)$ due to the injection of transpiring water at a low temperature to avoid salt plugging. Hot water, which comprises the major income of the system, was calculated as a negative value in the treatment cost and accounted for $-56.72 \$ \cdot \mathrm{t}^{-1}$. Thus, the total treatment cost for the SCWO system without OR is $56.80 \$ \cdot \mathrm{t}^{-1}$, with electricity and oxygen cost accounting for $81.30 \%$ and $31.69 \%$ of the total treatment cost, respectively.

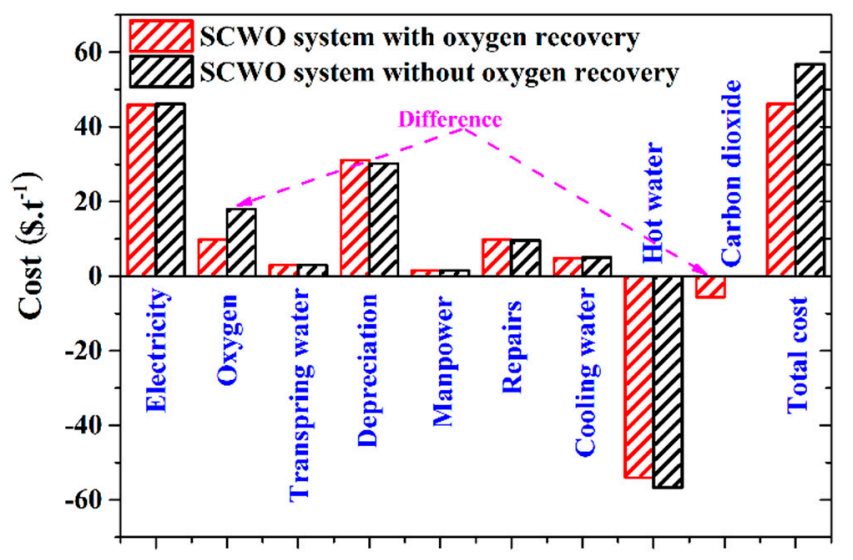

Figure 10. The treatment cost comparisons for SCWO systems with and without OR, the prices for electricity, oxygen, transpiring water and cooling water, are $0.079 \$ / \mathrm{kW} \cdot \mathrm{h}, 100 \$ \cdot \mathrm{t}^{-1}, 0.8 \$ \cdot \mathrm{t}^{-1}$, and $0.24 \$ \cdot \mathrm{t}^{-1}$, respectively; the manpower is $6000 \$ / \mathrm{man} \cdot$ year; the income for hot water and $\mathrm{CO}_{2}$ are $2.7 \$ \cdot \mathrm{t}^{-1}$ and $71.4 \$ \cdot \mathrm{t}^{-1}$, respectively.

Electricity, depreciation, and oxygen still contribute to the primary treatment cost of the SCWO system with OR. Electricity consumption slight decreases from $46.18 \$ \cdot \mathrm{t}^{-1}$ to $45.88 \$ \cdot \mathrm{t}^{-1} \mathrm{due}$ to OR, but oxygen cost significantly decreased from $18.01 \$ \cdot \mathrm{t}^{-1}$ to $9.77 \$ \cdot \mathrm{t}^{-1}$. Additionally, the additional income of $\mathrm{CO}_{2}$, which accounted for $-5.65 \$ \cdot \mathrm{t}^{-1}$, was obtained due to OR. Treatment cost considerably decreased from $56.80 \$ \cdot \mathrm{t}^{-1}$ to $46.17 \mathrm{\$} \cdot \mathrm{t}^{-1}$, with a reduction rate of $18.82 \%$. Thus, OR considerably contributes to reducing the treatment cost of an SCWO system.

\subsection{Effect of Stoichiometric Oxygen Excess}

On the basis of the previously designed system, this section investigates the effects of the operating parameters on energy consumption and treatment cost. Similar to the previous analysis, several episodes of actual oxygen consumption may be necessary for complete feed degradation. Thus, the effect of $R$ on the treatment cost of the SCWO systems with and without OR is analyzed in this section, and the operating parameters and detailed results are listed in Table 3(A1-A4, C1-C4) and Table 7(A1-A4, C1-C4). Electricity consumption and hot water income increase slightly with an 
increase in $R$ in both SCWO systems (Figure 11a,e). Oxygen consumption increases linearly with an increase in $R$ in the SCWO system without OR. When $R$ increased from 1.5 to 3, oxygen consumption considerably increased from $13.5 \$ \cdot \mathrm{t}^{-1}$ to $27 \$ \cdot \mathrm{t}^{-1}$ (Figure 11b). Furthermore, a slight increase in cooling water consumption (Figure 11d) occurs with an increase in $R$. An increase in $R$ has minimal effect on depreciation, repair (Figure 11c), transpiring water consumption, manpower (Figure 11d), and $\mathrm{CO}_{2}$ income (Figure 11e). Thus, the treatment cost of the SCWO system without OR can increase from $53.89 \$ \cdot \mathrm{t}^{-1}$ to $65.25 \$ \cdot \mathrm{t}^{-1}$ (Figure 11f) when $R$ increased from 1.5 to 3 . In the SCWO system with OR, oxygen consumption in the start-up stage is equal to that of the SCWO system without OR. However, the supplemental oxygen content is gradually reduced to a value that is slightly higher than the actual oxygen consumption after attaining OR equilibrium (Table 3 ). Thus, an increase in $R$ exerts minimal effect on oxygen consumption (Figure 11b). Moreover, high-purity $\mathrm{CO}_{2}$ can be recovered as an income due to OR (Figure 11e). In addition, equipment repairs and depreciation (Figure 11c), cooling water, transpiring water, and manpower consumption (Figure 11d) also exhibit minimal differences with varying $R$ values. Figure $11 \mathrm{f}$ shows that the treatment cost of the SCWO system with OR slightly increased from $46.63 \$ \cdot \mathrm{t}^{-1}$ at $R=1.5$ to $48.89 \$ \cdot \mathrm{t}^{-1}$ at $R=3$, which motivates us to operate the SCWO system with a high $R$ value for complete feed degradation.

Table 7. Electricity consumption for the SCWO system.

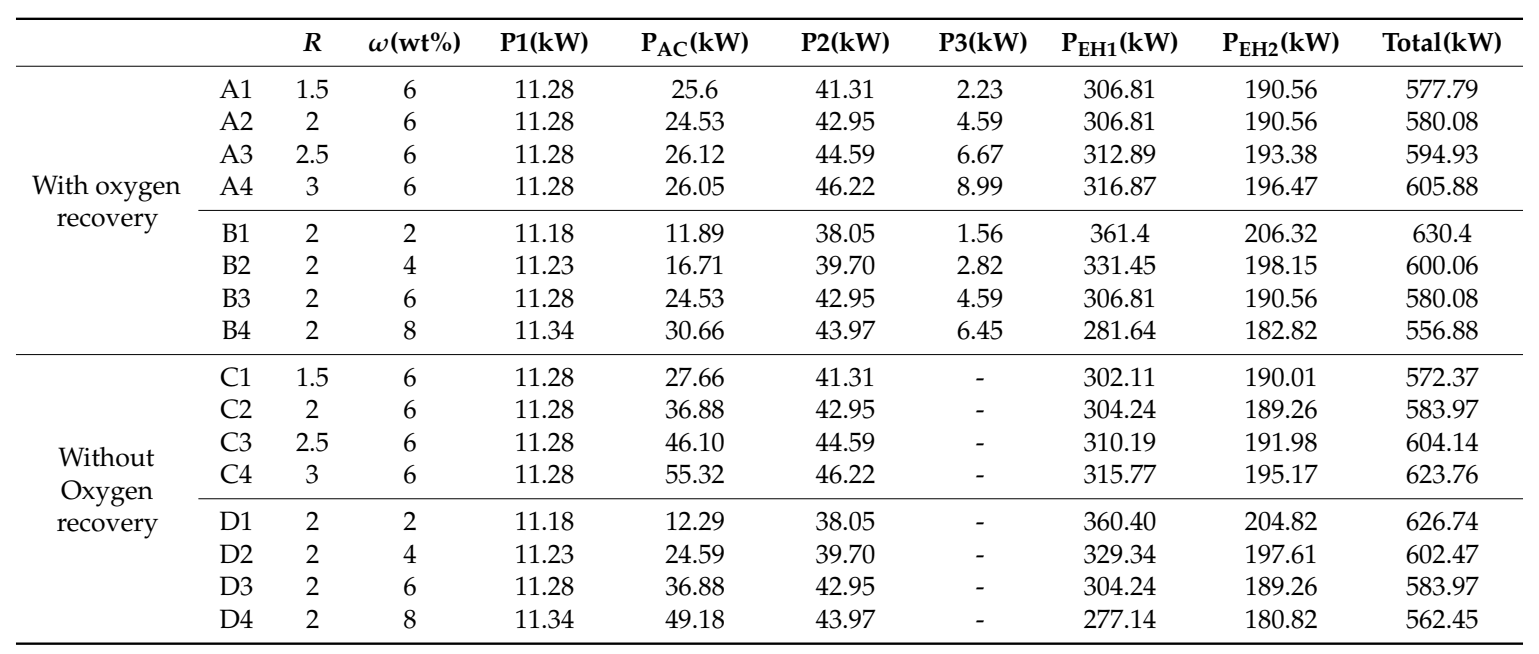
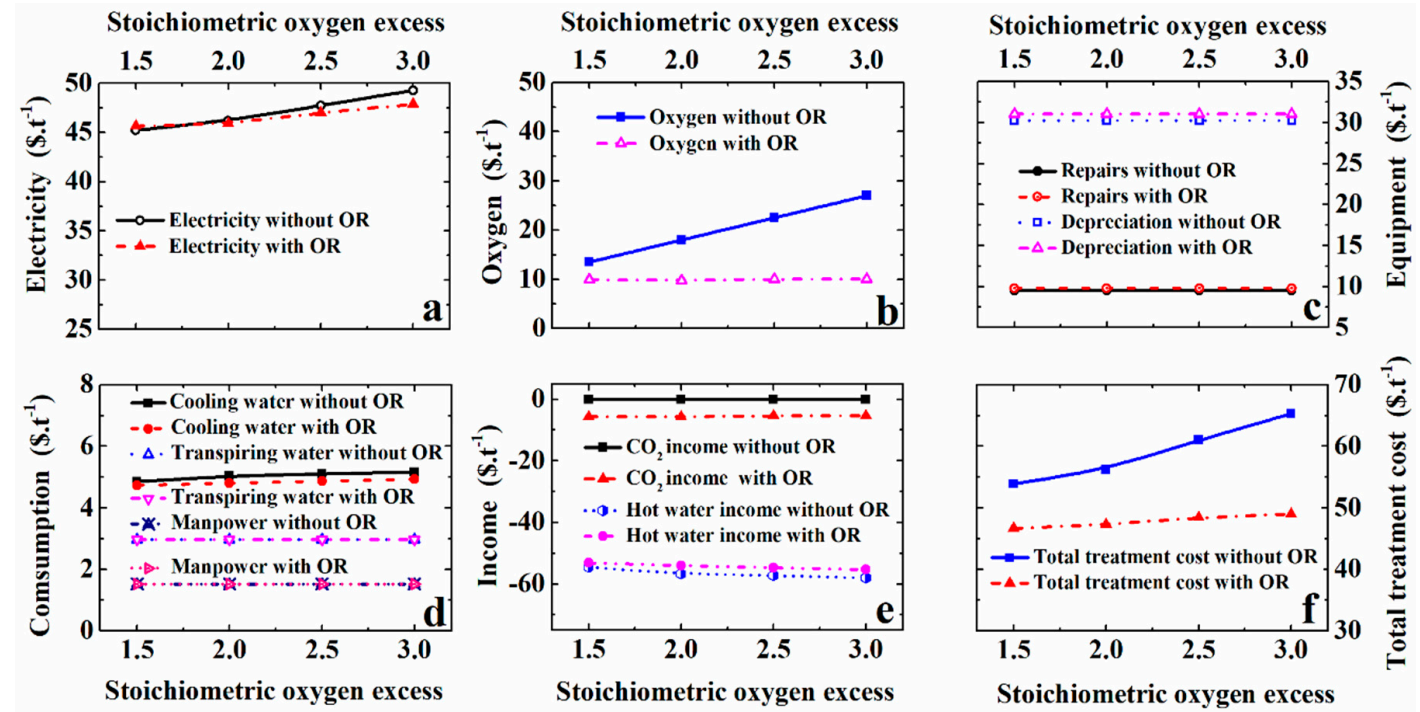

Figure 11. The effect of $R$ on the treatment cost for the SCWO system with and without OR, (a) electricity consumption, (b) oxygen consumption, (c) equipment repairs and depreciation, (d) cooling water, transpiring water, and manpower consumption, (e) $\mathrm{CO}_{2}$ and hot water income, and (f) total treatment cost. 


\subsection{Effect of the Feed Concentration}

The treatment cost for feed concentration between $2 \mathrm{wt} \%$ and $8 \mathrm{wt} \%$ is tested in this section under operating conditions, and the detailed results are listed in Table 3(B1-B4, D1-D4) and Table 7(B1-B4, D1-D4). When feed concentration increases, oxygen and transpiring water flow rates will also increase for feed degradation and reactor protection, and consequently, the electricity consumption of the pumps will also increase. However, reaction heat linearly increases with increasing feed concentration, and more heat can be recovered from the reactor effluent. Moreover, the preheating temperature of the feed at the starting and steady states can be reduced at a high feed concentration [40]. Thus, the total electricity consumption of the systems with and without OR decreased from $49.51 \$ \cdot \mathrm{t}^{-1}$ and $49.80 \$ \cdot t^{-1}$ to $44.35 \$ \cdot t^{-1}$ and $43.91 \$ \cdot t^{-1}$, respectively, when feed concentration was increased from 2 $\mathrm{wt} \%$ to $8 \mathrm{wt} \%$ (Figure $12 \mathrm{a})$.

Oxygen consumption significantly increased from $6.00 \$ \cdot \mathrm{t}^{-1}$ at $\omega=2 \mathrm{wt} \%$ to $24.00 \$ \cdot \mathrm{t}^{-1}$ at $\omega=8 \mathrm{wt} \%$ (Figure $12 \mathrm{~b}$ ), and hot water income considerably increased from $48.6 \$ \cdot \mathrm{t}^{-1}$ to $60.75 \$ \cdot \mathrm{t}^{-1}$ (Figure 12e) in the SCWO system without OR. Thus, treatment cost can increase from $54.82 \$ \cdot \mathrm{t}^{-1}$ at $\omega=2 \mathrm{wt} \%$ to $57.93 \$ \cdot \mathrm{t}^{-1}$ at $\omega=8 \mathrm{wt} \%$ (Figure $12 \mathrm{f}$ ). In the SCWO system with OR, when feed concentration was increased from $2 \mathrm{wt} \%$ to $8 \mathrm{wt} \%$, the supplemental oxygen content increased from $3.26 \$ \cdot t^{-1}$ to $13.05 \$ \cdot t^{-1}$, respectively (Figure $12 \mathrm{~b}$ ), and hot water and $\mathrm{CO}_{2}$ income increased from $47.25 \$ \cdot \mathrm{t}^{-1}$ and $1.57 \$ \cdot \mathrm{t}^{-1}$ to $58.05 \$ \cdot \mathrm{t}^{-1}$ and $7.22 \$ \cdot \mathrm{t}^{-1}$, respectively (Figure 12e). Figure $12 \mathrm{f}$ shows that the treatment cost of the SCWO system with OR decreased from $54.27 \$ \cdot \mathrm{t}^{-1}$ at $\omega=2 \mathrm{wt} \%$ to $42.06 \$ \cdot t^{-1}$ at $\omega=8 \mathrm{wt} \%$. Thus, an increase in feed concentration is conducive to reducing both the energy consumption and the treatment cost of the SCWO system with OR.
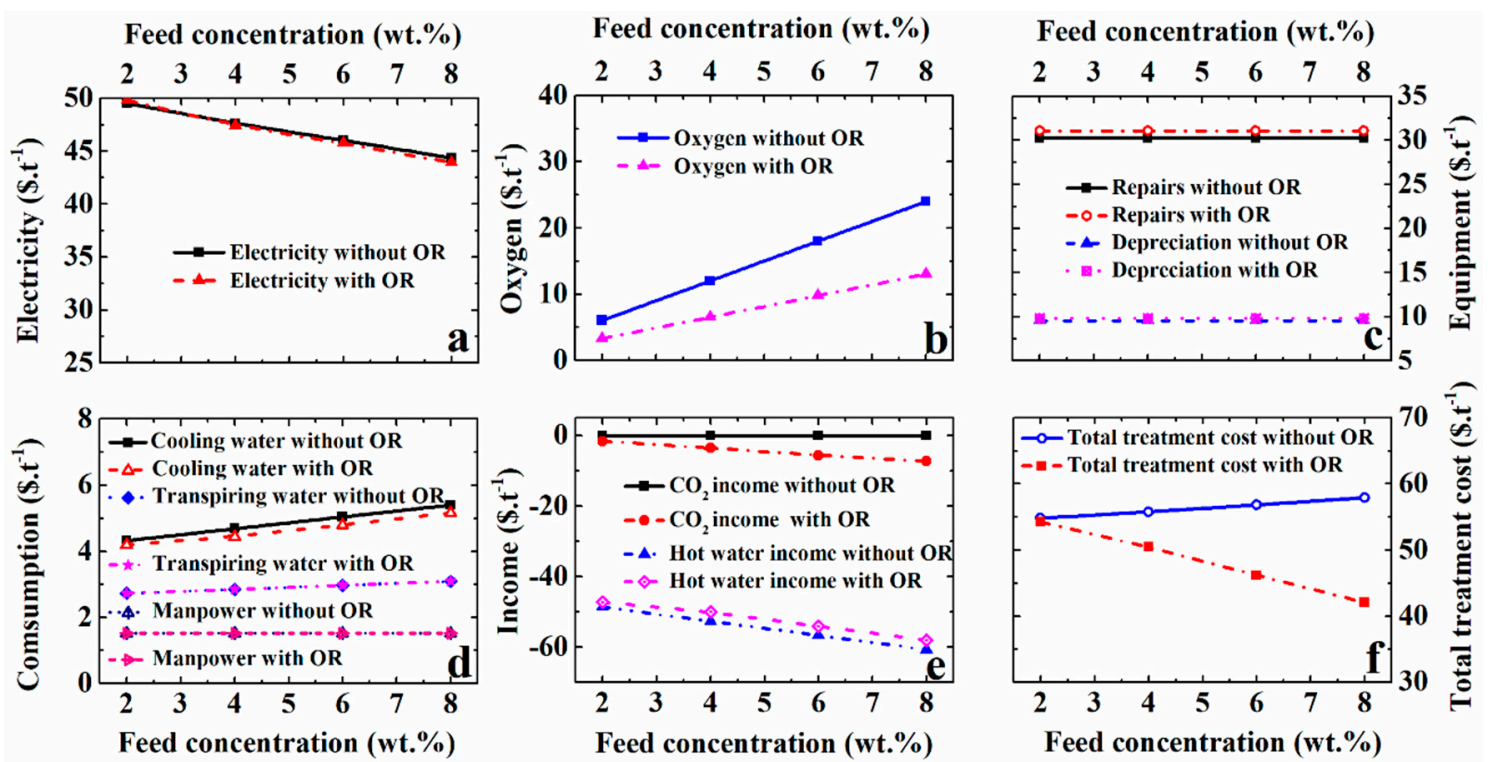

Figure 12. The effect of feed concentration on the treatment cost for a SCWO system with and without OR, (a) electricity consumption, (b) oxygen consumption, (c) equipment repairs and depreciation, (d) cooling water, transpiring water, and manpower consumption, (e) $\mathrm{CO}_{2}$ and hot water income, and (f) total treatment cost.

\section{Conclusions}

In this work, a species recovery process for an SCWO system with a TWR was first proposed based on the solubility difference between oxygen and $\mathrm{CO}_{2}$ in high-pressure water. Thus, oxygen and $\mathrm{CO}_{2}$ can be separated and recovered from the reactor effluent to reduce operating cost.

A two-step separation process was first established using Aspen Plus software to increase species recovery rate. Then, 10 potential thermodynamic models for high-pressure separation were evaluated and selected. The detailed recovery rates of oxygen and $\mathrm{CO}_{2}$ were compared with the ideal results 
calculated from the experimental solubility data. The PSRK model was proven to be an appropriate thermodynamic model for predicting the separation process of the reactor effluent under a wide range of conditions. Accordingly, the detailed optimized parameters for species separation were obtained.

The SCWO processes with and without OR were simulated and economic analyses were conducted. Electricity, depreciation, and oxygen costs contribute to the major treatment cost of the SCWO system without OR, accounting for $46.18,30.24$, and $18.01 \$ \cdot t^{-1}$, respectively. When OR was introduced, oxygen cost decreased from $18.01 \$ \cdot \mathrm{t}^{-1}$ to $9.77 \$ \cdot \mathrm{t}^{-1}$, and additional $\mathrm{CO}_{2}$ income, which amounted to $-5.65 \$ \cdot t^{-1}$, was gained due to OR. The total treatment cost considerably decreased from $56.80 \$ \cdot \mathrm{t}^{-1}$ to $46.17 \$ \cdot \mathrm{t}^{-1}$, with a reduction rate of $18.82 \%$. Thus, OR contributes to reducing the treatment cost of an SCWO system. In addition, $R$ and feed concentration increased and contributed to reducing the operating cost of the SCWO system with OR.

As a preliminary study of new SCWO system with OR, more experiments are needed to obtain more accurate results based on the simulation results in the future.

Author Contributions: F.Z. and C.M. put forward the idea of this work, F.Z. wrote this paper, J.C. conducted the simulation and calculation, F.Z., J.C., and C.S. contributed to the results analysis and post-processing.

Funding: This work is supported by National Natural Science Foundation (no. 51706049), Youth Innovation Promotion Association CAS (no. 2017412), and Science research project of Guangzhou City (201707010407).

Conflicts of Interest: The authors declare no conflict of interest.

\section{Nomenclature}

$\begin{array}{ll}\text { Abbreviations } \\ A & \text { area } \\ \text { AC } & \text { air compressor } \\ C & \text { capital } \\ \text { COD } & \text { chemical oxygen demand } \\ \text { EH } & \text { electric heater } \\ F & \text { mass flow rate, } \mathrm{kg} \cdot \mathrm{h}^{-1} \\ \text { FINAL } & \text { Final products } \\ F_{\mathrm{P}} & \text { pressure correction coefficient } \\ F_{\mathrm{M}} & \text { material correction coefficient } \\ \mathrm{HE} & \text { heat exchanger } \\ \mathrm{M} & \text { mixer } \\ \mathrm{OR} & \text { oxygen recovery } \\ P & \text { pressure } / \text { pump } \\ R & \text { transpiring intensity, universal gas constant } \\ \mathrm{S} & \text { Separator } \\ \mathrm{SCW} & \text { supercritical water } \\ \mathrm{SCWG} & \text { supercritical water gasification } \\ \mathrm{SCWO} & \text { supercritical water oxidation } \\ r & \text { reaction rate } \\ R & \text { stoichiometric oxygen excess } \\ t & \text { time, } \mathrm{s} \\ T & \text { temperature, }{ }^{\circ} \mathrm{C} \\ \text { tw1 } & \text { upper branch of transpiring water } \\ \text { tw2 } & \text { middle branch of transpiring water } \\ \text { tw3 } & \text { lower branch of transpiring water } \\ \text { TWR } & \text { transpiring wall reactor } \\ \text { TOC } & \text { total organic carbon, ppm } \\ X & \text { Design parameter } \\ & \end{array}$




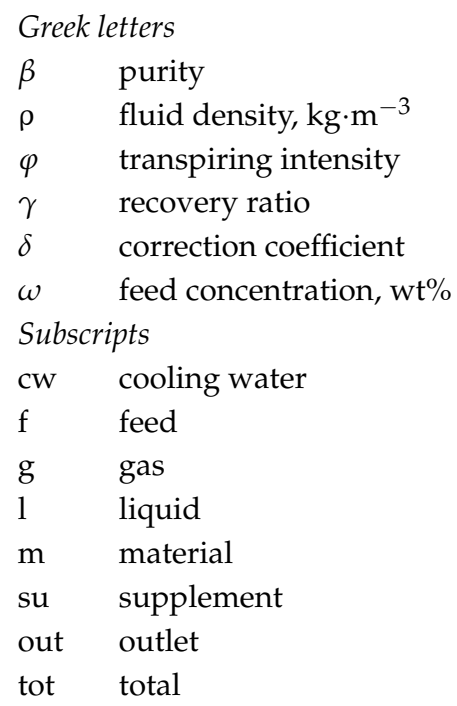

\section{References}

1. Akiya, N.; Savage, P.E. Roles of Water for Chemical Reactions in High Temperature Water. Chem. Rev. 2002, 33, 2725-2750. [CrossRef]

2. Xu, D.H.; Huang, C.B.; Wang, S.Z.; Lin, G.K.; Guo, Y. Salt deposition problems in supercritical water oxidation. Chem. Eng. J. 2015, 279, 1010-1022. [CrossRef]

3. Queiroz, J.P.S.; Bermejo, M.D.; Mato, F.; Cocero, M.J. Supercritical water oxidation with hydrothermal flame as internal heat source: Efficient and clean energy production from waste. J. Supercrit. Fluid 2015, 96, 103-113. [CrossRef]

4. Molino, A.; Migliori, M.; Blasi, A.; Davoli, M.; Marino, T.; Chianese, S.; Catizzone, E.; Giordano, G. Municipal waste leachate conversion via catalytic supercritical water gasification process. Fuel 2017, 206, 155-161. [CrossRef]

5. Fedyaeva, O.N.; Vostrikov, A.A.; Shishkin, A.V.; Dubov, D.Y. Conjugated processes of black liquor mineral and organic components conversion in supercritical water. J. Supercrit. Fluids 2019, 143, 191-197. [CrossRef]

6. Vadillo, V.; Belén García-Jarana, M.B.; Sánchez-Oneto, J.; Portela, J.R.; de la Ossa, E.J.M. Simulation of Real Wastewater Supercritical Water Oxidation at High Concentration on a Pilot Plant Scale. Ind. Eng. Chem. Res. 2011, 50, 2512-2520. [CrossRef]

7. Zhang, F.M.; Chen, S.Y.; Xu, C.Y.; Chen, G.F.; Ma, C.Y. Energy consumption analysis of a transpiring-wall supercritical water oxidation pilot plant based on energy recovery. Desalin. Water Treat. 2013, 51, 7341-7352. [CrossRef]

8. Fourcault, A.; García-Jarana, B.; Sánchez-Oneto, J.; Marias, F.; Portela, J.R. Supercritical water oxidation of phenol with air. Experimental results and modelling. Chem. Eng. J. 2009, 152, 227-233. [CrossRef]

9. Marrone, P.A. Supercritical water oxidation-Current status of full-scale commercial activity for waste destruction. J. Supercrit. Fluid 2013, 79, 283-288. [CrossRef]

10. Vadillo, V.; Sánchez-Oneto, J.; Portela, J.R.; de la Ossa, E.J.M. Problems in Supercritical Water Oxidation Process and Proposed Solutions. Ind. Eng. Chem. Res. 2013, 52, 7617-7629. [CrossRef]

11. Kritzer, P. Corrosion in high-temperature and supercritical water and aqueous solutions: A review. J. Supercrit. Fluid 2004, 29, 1-29. [CrossRef]

12. Hodes, M.; Marrone, P.A.; Hong, G.T.; Smith, K.A.; Tester, J.W. Salt precipitation and scale control in supercritical water oxidation-Part A: Fundamentals and research. J. Supercrit. Fluids 2004, 29, 265-288. [CrossRef]

13. Zhang, F.M.; Chen, S.Y.; Xu, C.Y.; Chen, G.F.; Zhang, J.M.; Ma, C.Y. Experimental study on the effects of operating parameters on the performance of a transpiring-wall supercritical water oxidation reactor. Desalination 2012, 294, 60-66. [CrossRef]

14. Bermejo, M.D.; Cocero, M.J. Supercritical water oxidation: A technical review. AIChE J. 2006, 52, $3933-3951$. [CrossRef] 
15. Xu, D.H.; Wang, S.Z.; Huang, C.B.; Tang, X.Y.; Guo, Y. Transpiring wall reactor in supercritical water oxidation. Chem. Eng. Res. Des. 2014, 92, 2626-2639. [CrossRef]

16. Kritzer, P.; Dinjus, E. An assessment of supercritical water oxidation (SCWO)-Existing problems, possible solutions and new reactor concepts. Chem. Eng. J. 2001, 83, 207-214. [CrossRef]

17. Kodra, D.; Balakotaiah, V. Autothermal oxidation of dilute aqueous wastes under supercritical conditions. Ind. Eng. Chem. Res. 1994, 33, 575-580. [CrossRef]

18. Lavric, E.D.; Weyten, H.; Ruyck, J.D.; Plesu, V.; Lavric, V. Delocalized organic pollutant destruction through a self-sustaining supercritical water oxidation process. Energy Convers. Manag. 2005, 46, 1345-1364. [CrossRef]

19. Cocero, M.J.; Alonso, E.; Sanz, M.T.; Fdz-Polanco, F. Supercritical water oxidation process under energetically self-sufficient operation. J. Supercrit. Fluids 2002, 24, 37-46. [CrossRef]

20. Bermejo, M.D.; Cocero, M.J.; Ferna'ndez-Polanco, F. A process for generating power from the oxidation of coal in supercritical water. Fuel 2004, 83, 195-204. [CrossRef]

21. Marias, F.; Mancini, F.; Cansell, F.; Mercadier, J. Energy recovery in supercritical water oxidation process. Environ. Eng. Sci. 2008, 25, 123-130. [CrossRef]

22. Lavric, E.D.; Weyten, H.; De Ruyck, J.; Plesu, V.; Lavric, V. Supercritical water oxidation improvements through chemical reactors energy integration. Appl. Therm. Eng. 2006, 26, 1385-1392. [CrossRef]

23. Jimenez-Espadafor, F.; Portela, J.R.; Vadillo, V.; Sánchez-Oneto, J.; Becerra Villanueva, J.A.; Torres García, M.; Martínez de la Ossa, E.J. Supercritical water oxidation of oily wastes at pilot plant: Simulation for energy recovery. Ind. Eng. Chem. Res. 2011, 50, 775-784. [CrossRef]

24. Zhang, F.M.; Shen, B.Y.; Su, C.J.; Xu, C.Y.; Ma, J.N.; Xiong, Y.; Ma, C.Y. Energy consumption and exergy analyses of a supercritical water oxidation system with a transpiring wall reactor. Energy Convers. Manag. 2017, 145, 82-92. [CrossRef]

25. Xu, D.H.; Wang, S.Z.; Gong, Y.M.; Guo, Y.; Tang, X.Y.; Ma, H.H. A demonstration plant for treating sewage sludge by supercritical water oxidation and its economic analysis. Mod. Chem. Ind. 2009, 29, 55-59.

26. Zhang, J.; Wang, S.Z.; Lu, J.L.; Chen, S.L.; Li, Y.H.; Ren, M.M. A system for treating high concentration textile wastewater and sludge by supercritical water oxidation and its economic analysis. Mod. Chem. Ind. 2016, 36, 154-158.

27. Shen, X.F.; Ma, C.Y.; Wang, Z.Q.; Chen, G.F.; Chen, S.Y.; Zhang, J.M.; Yi, B.K. Economic analysis of organic waste liquid treatment through supercritical water oxidation system. Environ. Eng. 2010, 28, 47-51.

28. Abeln, J.; Kluth, M.; Pagel, M. Results and rough costestimation for SCWO of painting effluents using a transpiring wall and a pipe reactor. J. Adv. Oxid. Technol. 2007, 10, 169-176.

29. Baranenko, V.I.; Fal'kovskii, L.N.; Kirov, V.S.; Kurnyk, L.N.; Musienko, A.N.; Piontkovskii, A.I. Solubility of oxygen and carbon dioxide in water. At. Energy 1990, 68, 342-346. [CrossRef]

30. Ma, C.Y.; Zhang, F.M.; Chen, S.Y.; Chen, G.F.; Zhang, J.M. A Method of Improving Oxygen Utilization Rate in Supercritical Water Oxidation System. Chinese Patent ZL 201010174846.9, 18 May 2010.

31. Holderbaum, T.; Gmehling, J. PSRK: A group contribution equation of state based on UNIFAC. Fluid Phase Equilib. 1991, 70, 251-265. [CrossRef]

32. Zhang, F.M.; Xu, C.Y.; Zhang, Y.; Chen, S.Y.; Chen, G.; Ma, C.Y. Experimental study on the operating characteristics of an inner preheating transpiring wall reactor for supercritical water oxidation: Temperature profiles and product properties. Energy 2014, 66, 577-587. [CrossRef]

33. Li, L.; Chen, P.; Gloyna, E.F. Generalized kinetic model for wet oxidation of organic compounds. AIChE J. 1991, 37, 1687-1697. [CrossRef]

34. Vogel, F.; Blanchard, J.L.D.; Marrone, P.A.; Rice, S.F.; Webley, P.A.; Peters, W.A.; Smith, K.A.; Tester, J.W. Critical review of kinetic data for the oxidation of methanol in supercritical water. J. Supercrit. Fluid 2005, 34, 249-286. [CrossRef]

35. Dagaut, P.; Cathonnet, M.; Boettner, J. Chemical Kinetic Modeling of the Supercritical-Water Oxidation of Methanol. J. Supercrit. Fluids 1996, 98, 33-42. [CrossRef]

36. Tester, J.W.; Webley, P.A.; Holgate, H.R. Revised global kinetic measurements of methanol oxidation in supercritical water. Ind. Eng. Chem. Res. 1993, 32, 236-239. [CrossRef]

37. Turton, R.; Bailie, R.C.; Whiting, W.B.; Bhattacharyya, D. Analysis, Synthesis and Design of Chemical Processes; Prentice Hall: Upper Saddle River, NJ, USA, 2012.

38. Shen, X.F. Design and Technical Economic Analysis on Heat Supply System by Supercritical Water Oxidation Energy Conversion. Master's Thesis, Shandong University, Jinan, China, 2009. 
39. Wildi-Tremblay, P.; Gosselin, L. Minimizing shell-and-tube heat exchanger cost with genetic algorithms and considering maintenance. Int. J. Energy Res. 2007, 31, 867-888. [CrossRef]

40. Zhang, F.M.; Zhang, Y.; Xu, C.Y.; Chen, S.Y.; Chen, G.F.; Ma, C.Y. Experimental study on the ignition and extinction characteristics of the hydrothermal flame. Chem. Eng. Technol. 2015, 38, 2054-2066. [CrossRef]

(c) 2018 by the authors. Licensee MDPI, Basel, Switzerland. This article is an open access article distributed under the terms and conditions of the Creative Commons Attribution (CC BY) license (http:/ / creativecommons.org/licenses/by/4.0/). 